\title{
OS MARKETPLACES E A MUDANÇA DO COMPORTAMENTO DO CONSUMIDOR
}

MILENA COHEN

TRABALHO DE CONCLUSÃO DE CURSO

CENTRO DE CIÊNCIAS SOCIAIS - CCS

DEPARTAMENTO DE ADMINISTRAÇÃO

Graduação em Administração de Empresas 
Milena Cohen

OS MARKETPLACES E A MUDANÇA DO COMPORTAMENTO DO CONSUMIDOR

Trabalho de Conclusão de Curso, apresentado ao Departamento de Administração da Pontifícia Universidade Católica do Rio de Janeiro PUC-Rio, como requisito parcial para a obtenção do título de graduação em Administração.

Orientador: Marcus Wilcox Hemais 


\section{Dedicatória}

Dedico este trabalho aos meus pais, Alberto e Betty e ao meu irmão, Gabriel, que não pouparam esforços para que eu alcançasse este grande objetivo da minha vida, graduação. Esta jornada não teria sido a mesma sem o apoio incondicional de vocês em todos os momentos. Estaremos sempre juntos nas vitórias e derrotas. Essa vitória é nossa! 


\section{Agradecimentos}

Gostaria de agradecer a toda minha família, que sempre me apoiou e suportou para que alcançasse todos os meus objetivos e me deu as oportunidades e caminhos para que eu me tornasse quem sou hoje.

A todos os meus colegas de faculdade e a PUC-Rio e outras instituições de ensino as quais frequentei pelas experiências e auxilio no meu desenvolvimento pessoal e profissional.

Aos meus amigos que me acompanham nos momentos mais diversos, sejam estes de vitória ou de desafio.

Ao meu orientador por toda ajuda e orientação para concluir este trabalho e todo apoio durante meu processo de graduação. 


\section{SUMÁRIO}

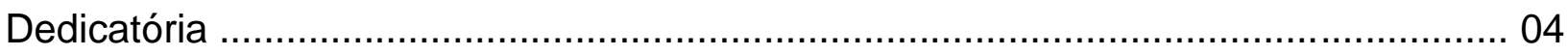

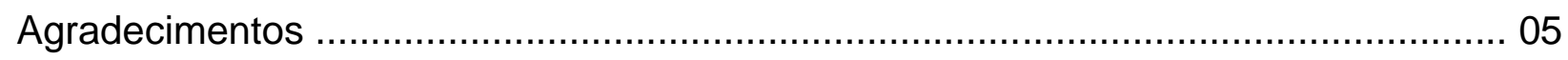

Sumário

06

Lista de Siglas e Abreviaturas

09

Lista de imagens

Lista de tabelas

Resumo

12

Abstract

1. INTRODUÇÃO 14

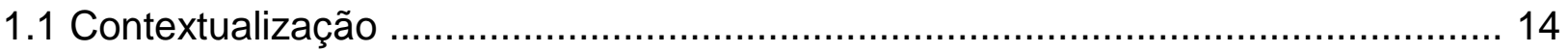

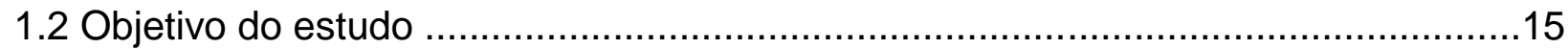

$\begin{array}{llcl}1.3 & \text { Relevância } & \text { do } & \text { estudo } \\ 1.4 & \text { Delimitação } & \text { do } & \text { tema }\end{array}$

2. DADOS SOBRE MARKETPLACE

2.1 A Era da internet $\mathrm{e}$ as mudanças no consumo .................................................. 17

2.2 Cronologia do Marketplace no mundo .18

2.3 Marketplace no Brasil 20 
2.4 Vantagens do Marketplace para os consumidores 22

2.5 Vantagem do Marketplace para os vendedores 24

2.6 Marketplace dentro do E-commerce 25

2.7 Marketplace durante a pandemia 26

3. REFERENCIAL TEÓRICO 29

3.1 O que é o comportamento do consumidor e qual sua importância? 31

3.2 Mudança de comportamento do consumidor e influências 32

3.3 Percepção do consumidor 33

3.4 Atitude do consumidor 35

4. MÉTODO DO ESTUDO 38

4.1 Tipo de pesquisa 38

4.2 Seleção dos entrevistados 38

4.3 Coleta dos dados .40

4.4 Tratamento dos dados 41

4.5 Limitações do método 41 


\section{ANÁLISE DOS DADOS 42}

5.1 Visão geral sobre conhecimento de marketplaces 42

5.2 Percepção dos consumidores sobre o Mercado Livre 43

5.3 Atitude dos consumidores sobre o Mercado Livre 45

6. CONCLUSÃO

49

6.1 Implicações gerenciais 49

6.2 Sugestões de futuros estudos 50

\section{REFERÊNCIAS}

51

8. APÊNDICE 1

58

9. APÊNDICE 2

61 


\section{Lista de siglas e Abreviaturas}

SBVC: Sociedade Brasileira de Varejo e Consumo

B2B: Transações entre Empresas

B2C: Transações Entre Empresas e Consumidores

C2C: Transações Entre Consumidores

C2G: Transações Entre Consumidores e Órgãos Governamentais

E-BIT: Site de Pesquisa de Comércio Eletrônico 
E-COMMERCE: Comércio Eletrônico

\section{Lista de imagens}

FIGURA 1 Marketplace e E-commerce ............................................................... 20

FIGURA 2 Evolução do E-commerce no Brasil .................................................... 21

FIGURA 3 Confiança no Marketplace ........................................................... 23

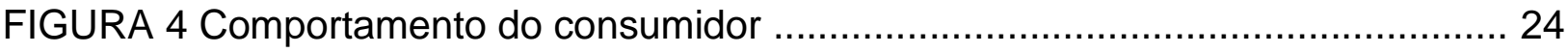

FIGURA 5 Faturamento de Marketplaces ................................................ 26

FIGURA 6 Recorde no E-commerce 28 


\section{Lista de tabelas}

Tabela 1 - Perfil dos Entrevistados

41 


\section{RESUMO}

Os e-commerce revolucionaram o mercado consumidor. Trata-se de plataformas de compra e venda de serviços ou produtos online e recebimento destes em um local físico, da escolha do cliente, que, em geral, paga o valor de frete pré-estabelecido pela marca dona do produto. A partir disso, tem-se como modalidade do e-commerce o marketplace - loja virtual que possui vários fornecedores os quais vendem para lojistas, gerando uma maior variedade de preços e promovendo um maior nicho de consumidores.

Esse estudo analisou como a inserção do marketplace modificou a relação do consumidor com o mercado. Assim sendo, fez-se uma pesquisa qualitativa exploratória, por meio de uma entrevista roteirizada, com a exposição de um vídeo sobre os marketplaces, em que buscou-se entender como os consumidores se relacionam com as plataformas. Após a coleta destes dados, foi feita a análise e a observação das mudanças, a partir das quais se concluiu que a pandemia impulsionou o crescimento dos marketplaces e que essa tendência de mercado é cada vez mais parte integral dos hábitos de consumo contemporâneos.

PALAVRAS CHAVE: Marketplace, Consumidor, E-commerce,. 


\section{ABSTRACT}

E-commerce has revolutionized the consumer market. "E-commerce" is the term that defines the plataforms for purchasing and selling services or products online and receiving them at a location chosen by the costumer, who, in general, pay a fee preestablished by the brand to this delivery. Based on this, the marketplace is a modality of e-commerce - a virtual store that has several suppliers which sell to retailers, providing a greater variety of prices and having a broader niche of consumers.

Thus, this study analyzed how the insertion of the marketplace changed the relationship of consumer on the market. Therefore, a qualitative research was carried out, through a scripted interview, with the exhibition of a video of marketplaces which sought to understand how consumers relate to marketplaces. After the gathering of this data, the analyze and observation of the transformations suffered by the market, and it was concluded that the pandemic has contributed to the growth of the marketplaces and that this trend is increasingly an integral part of contemporary consumer habits.

KEY WORDS: Marketplace, Consumer, E-commerce. 


\section{INTRODUÇÃO}

\subsection{Contextualização}

A internet se popularizou, no Brasil, entre o final da década de 1990 e o início dos anos 2000. Nesse período, ganham destaque as primeiras páginas virtuais de comércio popular, que, ao longo desse tempo, passam a ter um aumento significativo de visibilidade, atraindo os consumidores (E-COMMERCE BRASIL, 2019). Com esse avanço das tecnologias e da própria internet, que, diariamente, ganha mais usuários, torna-se difícil, para os comerciantes, manterem seu patamar de vendas caso não se aprimorem constantemente. Com base nisso tudo, percebe-se que, há alguns anos, uma modalidade de comércio eletrônico tem ganhado bastante visibilidade: o marketplace.

Essa modalidade de comércio se diferencia pelo fato de abrigar, em uma única plataforma, diferentes lojas, vendedores e comerciantes, no geral. O marketplace ainda tem o diferencial de gerar um grande aumento no faturamento, uma vez que o investimento inicial feito para poder anunciar e manter o produto nessa plataforma é baixo se considerado com os lucros obtidos (ROEBER, 2015).

O fato de poder fazer compras do sofá de casa, por meio de um dispositivo eletrônico, é uns dos principais atrativos dessa forma de comercialização, visto que a população, que normalmente possui uma rotina extensa de trabalho diário, encontra na internet a superação dessa barreira, pois pode escolher o melhor horário que pretende comprar, visto que o site estará à disposição 24 horas por dia.

Por ser um modelo inovador e diferenciado, o marketplace tem se fortalecido no mercado. Além de vantagens individuais aos vendedores e clientes, como o possível aumento de vendas e maior visibilidade para os produtos oferecidos, já que se anuncia em um site de renome, ele também permite que o consumidor tenha segurança ao adquirir um produto de qualquer lugar em que esteja.

Ao analisar o comportamento de consumidor atual, no contexto da Era da internet, percebe-se que mesmo sendo bastante recente no país, o crescimento do 
marketplace dentro do e-commerce nacional aumenta a passos largos, já sendo responsável por parcela considerável do faturamento total. Portanto, faz se importante entender como o consumidor se relaciona com esse meio de comércio.

O presente estudo, portanto, analisa percepções e atitudes de consumidores quanto a marketplaces. Pretende-se elencar e delimitar os elementos que mais atraem os consumidores para essa modalidade de comércio de modo a oferecer novos insights e estratégias para os administradores desses negócios, que cada vez mais estabelecem sua presença no e-commerce, e na vida dos usuários da rede.

\subsection{Objetivo do estudo}

Este trabalho tem como finalidade analisar a percepção e a atitude do consumidor em relação ao marketplace. Para isso, será realizada uma pesquisa qualitativa, na forma de entrevistas com 20 consumidores que já fizeram compras em marketplaces no Brasil.

\subsection{Relevância do estudo}

O presente estudo tem relevância acadêmica e empresarial. Em relação à relevância acadêmica, como o marketplace é um conceito razoavelmente recente, ainda há pouca literatura de Marketing e outras áreas sobre o assunto. Portanto, o conhecimento acerca da relação do consumidor, no Brasil, com o marketplace é superficial. Dessa maneira, ao trazer conhecimento sobre a percepção e atitude do consumidor em relação a essa nova forma de comércio eletrônico, busca-se contribuir academicamente de modo que se consiga entender melhor esse fenômeno.

Nesse sentido, o trabalho também possui relevância empresarial, visto que permite a empresas que utilizam o marketplace um melhor entendimento a respeito de quem é o consumidor que usa este serviço e qual seu perfil geral. Dessa forma, espera-se que, com a produção deste trabalho e divulgação dele para a população 
nacional, as companhias possam se inspirar aprimorar cada vez mais no atendimento de seu público.

\subsection{Delimitação do tema}

No trabalho, em questão, são traçadas duas principais delimitações. A primeira é a delimitação teórica a qual, por meio do referencial teórico, irá expor a atitude e a percepção do consumidor em relação ao marketplace. Para isso, será utilizado o exemplo de um marketplace bem-sucedido no Brasil: Mercado Livre.

Após a delimitação do tema, será apresentada a pesquisa empírica que procurou analisar o relacionamento dos consumidores com o marketplace Mercado Livre, objeto principal do presente estudo qualitativo. 


\section{DADOS SOBRE MARKETPLACE}

De forma a descobrir se o marketplace está ou não plenamente solidificado no Brasil, este capítulo apresenta informações sobre a presença e atuação dos marketplaces na economia brasileira, bem como a relação dos consumidores com essa forma de comércio.

\subsection{A Era da internet $e$ as mudanças no consumo}

Para entender a realidade do marketplace, hoje, é importante saber como esse modelo surgiu. Nascido em meados da década de 1990, com as empresas Amazon e Ebay, o marketplace segue revolucionando a forma de se consumir. No Brasil, a chegada do marketplace não foi imediata, sendo que os primeiros indícios dele no país são apenas do início dos anos 2000 (E-COMMERCE BRASIL, 2019).

De qualquer forma, ainda levou mais algum tempo para que ele se tornasse o sucesso que é atualmente. Segundo Nicolau (2020), o "boom" do marketplace, no Brasil, é recente, sendo que sua grande expansão se deu a partir de 2016, mas, até hoje, segue forte. O autor ainda afirma que, em 2019, o comércio eletrônico teve um faturamento total de 27 bilhões, no Brasil, e que, no mesmo período, o marketplace teve uma receita de 18 bilhões.

O consumidor brasileiro tem, cada vez mais, buscado se adequar às tendências do mercado. Dessa forma, desde que começou a se popularizar, os marketplaces invadiram as casas e fizeram um enorme sucesso. Esse fato é tão relevante que, de acordo o blog NEILPATEL ([S.I.], 2020), o Brasil é o terceiro país que mais faz compras pela internet, liderando o ranking de comércio eletrônico na América Latina, com participação nas compras de 59,1\%, enquanto o segundo colocado, México, representa apenas $14,2 \%$ do montante.

Esse perfil é resultado direto da popularização da internet e do aumento do acesso das classes mais baixas ( $C$ e D) a ela, ajudando a corroborar o forte poder de compra que a população já começa a mostrar. Ainda que esse aumento só tenha sido 
realmente notado há pouco tempo, em 2013, Pires (2013) já escrevia sobre isso em uma coluna do website E-commerce:

O mercado eletrônico encontra-se em constante crescimento dentro das classes mais baixas. $O$ aumento do acesso à Internet pelas classes $C$ e $D$ e uma considerável melhora na segurança da Internet criam um cenário de oportunidades. (PIRES, 2013)

Arraes (2019) diz que o comportamento do consumidor foi profundamente transformado pela internet, visto que, antes, para se escolher a melhor opção de compra, o consumidor precisava andar muito e ir a diversas lojas até conseguir ter, em mãos, o comparativo real de preços. Hoje, esse mesmo comparativo de preços é passível de ser feito com apenas alguns cliques, facilitando e otimizando a vida dos clientes.

O uso da internet contribui para a mudança no comportamento do consumidor. Em 2018, de acordo com a 39a edição do Webshoppers, desenvolvido pela Ebit | Nielsen, o e-commerce brasileiro apresentou crescimento nominal de $12 \%$ no volume de pedidos e ganhou 10 milhões de consumidores que fizeram, pela primeira vez, uma compra online. Isto se dá, principalmente pela inclusão digital que vem acontecendo no país, por meio da expansão do mercado de smartphones e do acesso à banda larga. (CZARNOBAI, 2019).

Nesse sentido, além de propiciar ganhos ao mercado e mais acesso à informação, a internet mudou o comportamento do consumidor brasileiro, de tal forma que, hoje, principalmente após o cenário imposto pela pandemia do novo Coronavírus, deverá se tornar tendência comprar por meio de alguns cliques diretamente do conforto da casa.

\subsection{Cronologia do marketplace no mundo}


O comércio é algo presente na sociedade desde os tempos antigos. No Brasil, por exemplo, o primeiro tipo de troca comercial conhecido, ou seja, o escambo (troca entre nativos e invasores em que os nativos ofereciam sementes, mudas, plantas, e outros bens advindos diretamente da natureza, e recebiam dos invasores miçangas, espelhos, pentes e outras quinquilharias), foi estabelecido pelos europeus tão logo estes colonizaram o país. Logicamente, com o passar do tempo, essa prática foi aprimorada e refinada, chegando, atualmente, a modelos mais desenvolvidos, que largamente utilizam a internet para que consigam funcionar, como o próprio marketplace.

As primeiras atividades deste modelo de negócio foram observadas no início da década de 1990 nos Estados Unidos com o surgimento de grandes nomes como a Amazon e o eBay. Mesmo que gradativamente, estas empresas foram crescendo e se tornaram gigantes do mercado digital. (RIBEIRO, 2020)

Segundo Almeida (2017), a primeira empresa virtual de venda de que se tem notícia é o eBay. Surgida no ano de 1995, a plataforma desenvolvida pelo francês Pierre Omidyar foi inicialmente chamada de AuctionWeb, mas dois anos após sua fundação, em 1997, ela passa a ser conhecida como eBay. Uma outra plataforma, largamente conhecida e utilizada pelos brasileiros é o Mercado Livre. Na América Latina, a relevância das duas plataformas é tão grande que ambas possuem uma sociedade juntas, o que ajuda a garantir e solidificar a importância delas neste continente. Aliado a isso, de 1995 até os dias atuais, inúmeras outras empresas do ramo surgiram e ganharam o mercado mundo à fora.

A Figura 1 ajuda a elucidar o surgimento de marketplaces ao redor do planeta, bem como permite que se entenda de maneira mais pontual a evolução de cada um deles: 
Figura 1: Cronologia do Marketplace no mundo.

\section{Evolução cronológica do marketplace no mundo}

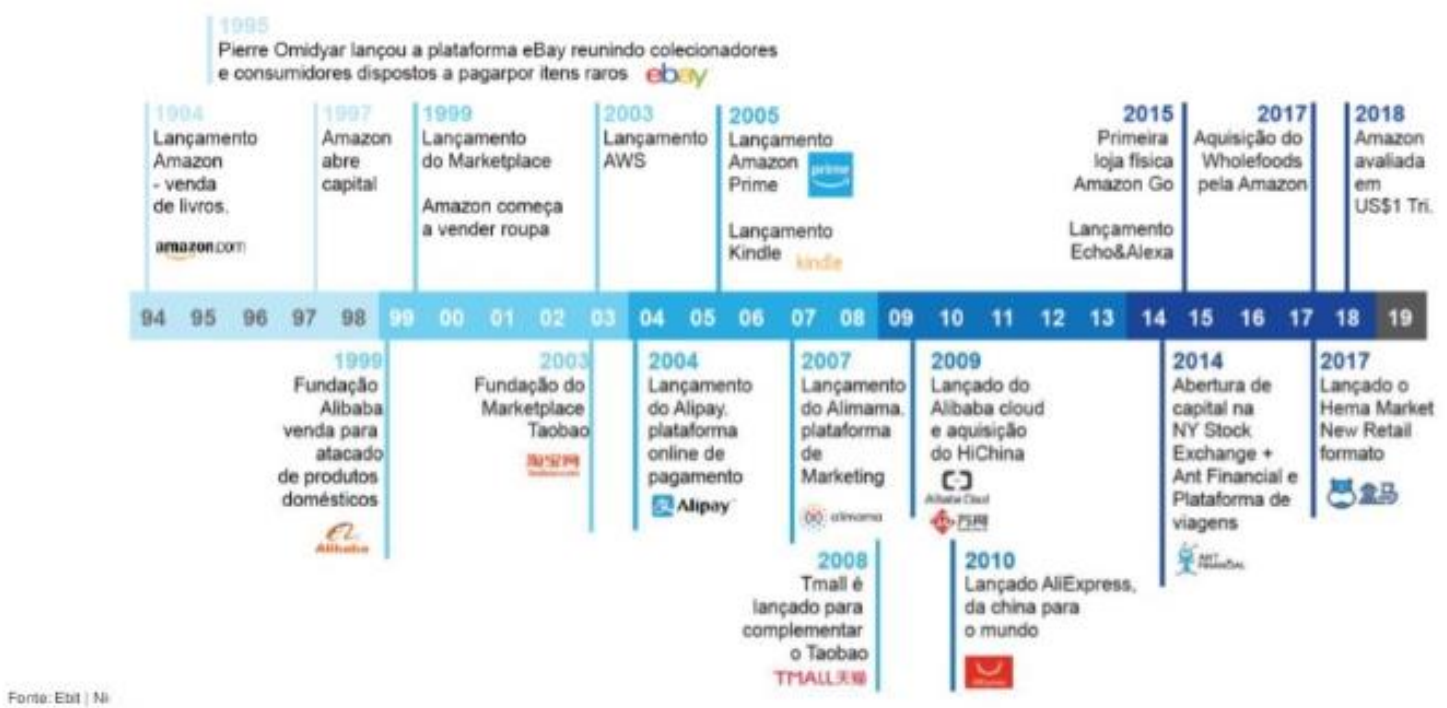

Fonte: Ebit/Nielsen

\subsection{Marketplace no Brasil}

Conforme aponta a edição 37 do Webshoppers, realizada pela Ebit/Nielsen, o ano de 2017 foi marcado pelo fortalecimento das transações realizadas em marketplaces, crescendo $21,9 \%$ em relação a 2016 - ano da sua grande expansão.

Dos marketplaces que compartilham os dados com a Ebit/Nielsen, é possível ter uma percepção da relevância desse modelo no Brasil. Somente no primeiro semestre de 2019, o marketplace teve um crescimento de $13 \%$, comparado aos $12 \%$ da média do e-commerce. O faturamento, por sua vez, foi de $\mathrm{R} \$ 17,6$ bilhões, enquanto o e-commerce faturou $\mathrm{R} \$ 26,4$ bilhões. A pequena diferença do faturamento em relação ao crescimento médio mostra que o marketplace está ganhando cada vez mais adeptos. (E-COMMERCE, 2019) 
Zacho (2017), no artigo "O que é marketplace: veja as vantagens e desvantagens" do site E-commerce, relata que os maiores marketplaces brasileiros têm uma enorme audiência, reunindo em média 40 milhões de potenciais compradores. Isso, por sua vez, amplia a quantidade de interessados no produto ofertado, gera mais demanda e visibilidade aos vendedores.

De acordo com pesquisa da PwC e UPS, realizada em 2020, 95\% dos consumidores brasileiros que realizam suas compras dentro do ambiente virtual fazem isso por meio de um marketplace; e $44 \%$ deles afirmaram que farão mais aquisições nessas plataformas dentro de um ano. (NICOLAU, 2020).

Dessa maneira, percebe-se que mesmo com menos de 3 décadas no mercado brasileiro, o marketplace já tem alcançado resultados satisfatórios, com rendimentos econômicos admiráveis, que legitimam seu crescimento e mais investimentos nessa área.

A seguir tem-se uma figura extraída do site Ebit/Nielsen que mostra a evolução do comércio eletrônico no Brasil, demonstrando o grande faturamento que o comércio eletrônico tem alcançado no decorrer desses anos.

Figura 2: Evolução do E-commerce no Brasil

\begin{tabular}{|c|c|c|c|c|}
\hline$\underset{(2000)}{R \$ 500 m i}$ & $\begin{array}{c}\mathrm{R} \$ 2,5 \mathrm{bi} \\
(2005)\end{array}$ & $\begin{array}{c}\mathrm{R} \$ 10 \mathrm{bi} \\
\underset{(2010)}{ }\end{array}$ & $\begin{array}{c}\mathrm{R} \$ 41 \mathrm{bi} \\
\underset{(2015)}{ }\end{array}$ & $\begin{array}{c}\mathrm{R} \$ 53 \mathrm{bi} \\
\underset{(2018)}{ }\end{array}$ \\
\hline $1995-2000$ & $2001-2005$ & $2006-2010$ & $2011-2015$ & $2016-2019$ \\
\hline
\end{tabular}




\subsection{Vantagens do Marketplace para os consumidores}

Um dos principais pontos positivos, para os consumidores, dentro dos marketplaces, é a oportunidade de poder comparar o preço de um mesmo produto em várias lojas. Dessa forma, em segundos, os consumidores sabem qual loja trará maior vantagem econômica.

Além disso, o fato de lojas pequenas estarem dentro de um ambiente maior, mais seguro e muito mais conhecido faz com que os consumidores tenham mais segurança e confiabilidade na hora da compra. Segundo o site E-commerce, um dos fatores que mais atrai os consumidores é a existência de promoções. Isso acontece porque o consumidor com acesso ao comparativo de preços já busca por produtos que Ihe tragam vantagem econômica maior.

Portanto, a existência de promoções ou outros atrativos é um incentivo a mais para uma loja ser a escolhida para a compra. O marketplace "é considerado vantajoso para o consumidor, visto que reúne diversas marcas e lojas em um só lugar, facilita a procura pelo melhor produto e melhor preço" (ZACHO, 2017).

Outras vantagens de comprar em marketplaces é o fato de ele: oferecer mais opções de fretes, que vão desde preços altíssimos até preços irrisórios ou gratuitamente; permitir que o consumidor saiba o tempo estimado para a entrega chegar até seu endereço; e não deixar que uma venda seja perdida, uma vez que, caso o produto não esteja em estoque, a empresa dona do marketplace pode ela mesma comprar o produto, revende-lo ao cliente e ainda garantir que a entrega seja enviada dentro do prazo previamente estipulado.

A Figura 3 ilustra o que o consumidor considera mais importante no marketplace de acordo com a pesquisa realizada. 
Figura 3: Confiança em Marketplace

Você é fiel a algum/alguns marketplaces?

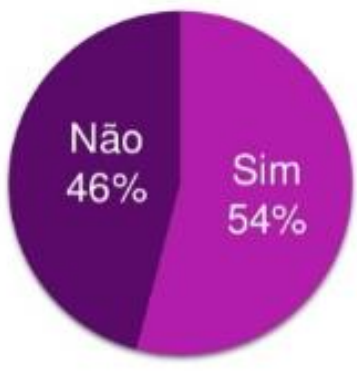

Para ser fiel a um marketplace, o que é mais importante?

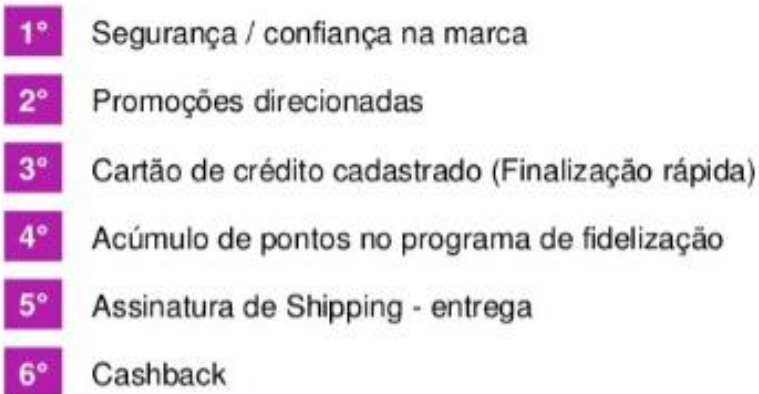

Fonte: Ebit/Nielsen

De acordo com a pesquisa realizada pela Ebit/Nielsen, mais da metade dos entrevistados diz ser fiel a um marketplace, o que é muito importante para a empresa, pois garante um público fixo para o consumo de seus produtos. Outro aspecto bastante interessante é o fato de que, para o cliente, o mais importante é a segurança ao fazer a compra. Assim, estar sob a égide de um marketplace ajuda lojas pequenas a conseguirem vender e, ao mesmo tempo, traz certa tranquilidade para o consumidor em potencial. Por fim, a reputação da loja vendedora, a quantidade de vendas já realizadas, a presença ou não de dados confiáveis para contato e os comentários de outros compradores também ajudam a assegurar o consumidor de que o marketplace é um ambiente seguro e confiável.

Por último, a Figura 4 mostra qual o principal motivo para que os consumidores usem o marketplace. 
Figura 4: Comportamento do cconsumidor
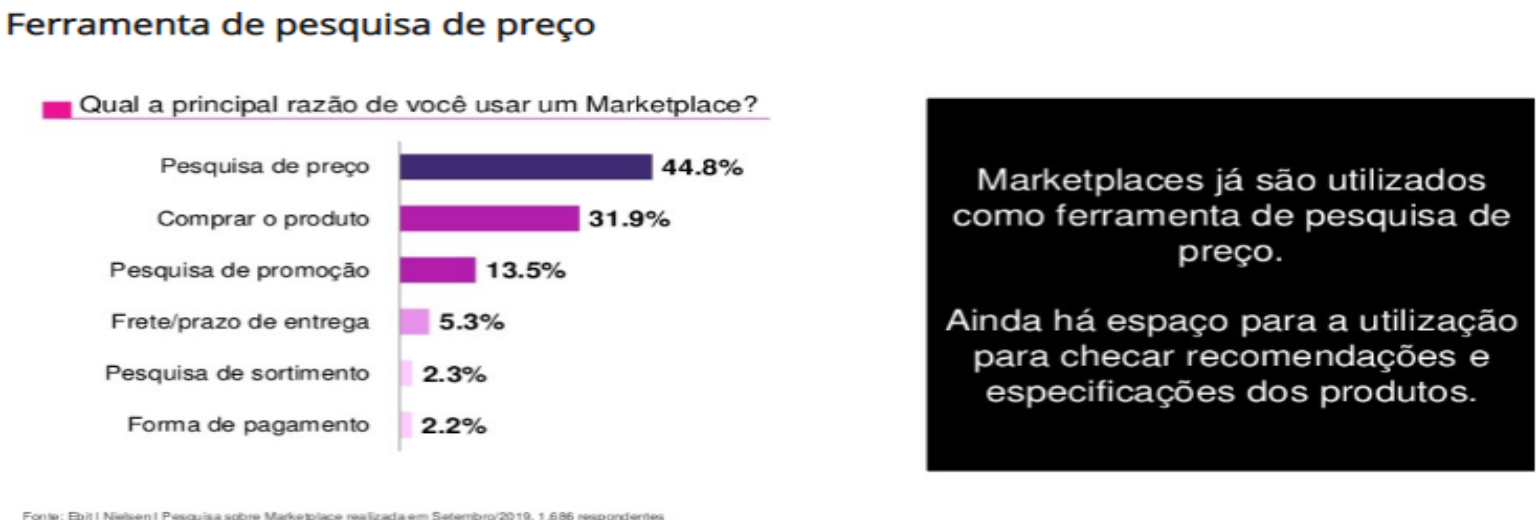

Fonte: Ebit/Nielsen

Não é novidade que o comparativo de preços está em primeiro lugar, haja visto que o preço de um produto age como um dos maiores diferenciais dessa modalidade. Dessa maneira, ter uma variedade grande de valores, que consiga satisfazer tanto o consumidor de classe média baixa quanto o que possui maior renda, apesar de ser um desafio, também é um grande atrativo. O consumidor, ao acessar o marketplace, encontra muitas informações em uma plataforma só, e isso é uma enorme vantagem quando se está pensando em adquirir um produto.

\subsection{Vantagens dos Marketplaces para os vendedores}

Há muitas vantagens para lojistas, produtores, vendedores e comerciantes em ambientes de comércio eletrônico, como o marketplace. Pode-se citar como duas delas: a visibilidade que o comércio ganhará em uma plataforma maior e mais conhecida, levando muitos usuários e clientes com necessidades e condições econômicas diversas a terem contato diário com o comércio; e acréscimo nos lucros devido ao aumento de vendas. 
Já que o investimento é baixo, uma vez que o marketplace oferece ao vendedor tudo o que ele precisa para iniciar suas vendas (local virtual para vender, opções de Marketing, exibição de produtos e diferentes opções de entrega), o lucro gerado com o uso dessa plataforma é praticamente garantido e certo. Não é preciso, também, um conhecimento muito específico em informática para acessar e cadastrar uma loja e produtos em um marketplace, o que acaba por agir como mais uma vantagem para os vendedores, que, muitas vezes, não têm conhecimento na área.

\subsection{Marketplace dentro do E-commerce}

O marketplace é uma modalidade do E-commerce, é importante que se entenda que cada um possui suas particularidades. "Enquanto um e-commerce se baseia na comercialização de produtos e serviços por meio de um site focado apenas nas vendas de uma só loja virtual, o marketplace conta com uma proposta mais abrangente." (RIBEIRO, 2020, p.02).

Dessa maneira, no marketplace, por exemplo, o estoque é descentralizado, o preço do produto é definido pelo o fornecedor; há intermédio de negócio; e a logística é acertada entre o fornecedor e o cliente. Por sua vez, no e-commerce: o estoque é centralizado; a própria marca é quem define o preço do produto; a logística é feita por meio do fornecedor, que passa ao varejista e, então, ao cliente; e somente a modalidade de compra e venda é possível de ser realizada.

Apesar dessas diferenças importantes, ambos se complementam. $O$ marketplace tem feito um rendimento bastante positivo dentro do e-commerce. A figura 5, retirada da $42^{\mathrm{a}}$ edição da Webshoppers, realizada pela Ebit/Nielsen em parceria com a Elo, demonstra o faturamento do marketplace nacional no $1^{\circ}$ semestre de 2020 , que teve um crescimento de $56 \%$ se comparado com o mesmo período do ano passado (2019). 
Figura 5: Faturamento de Marketplaces

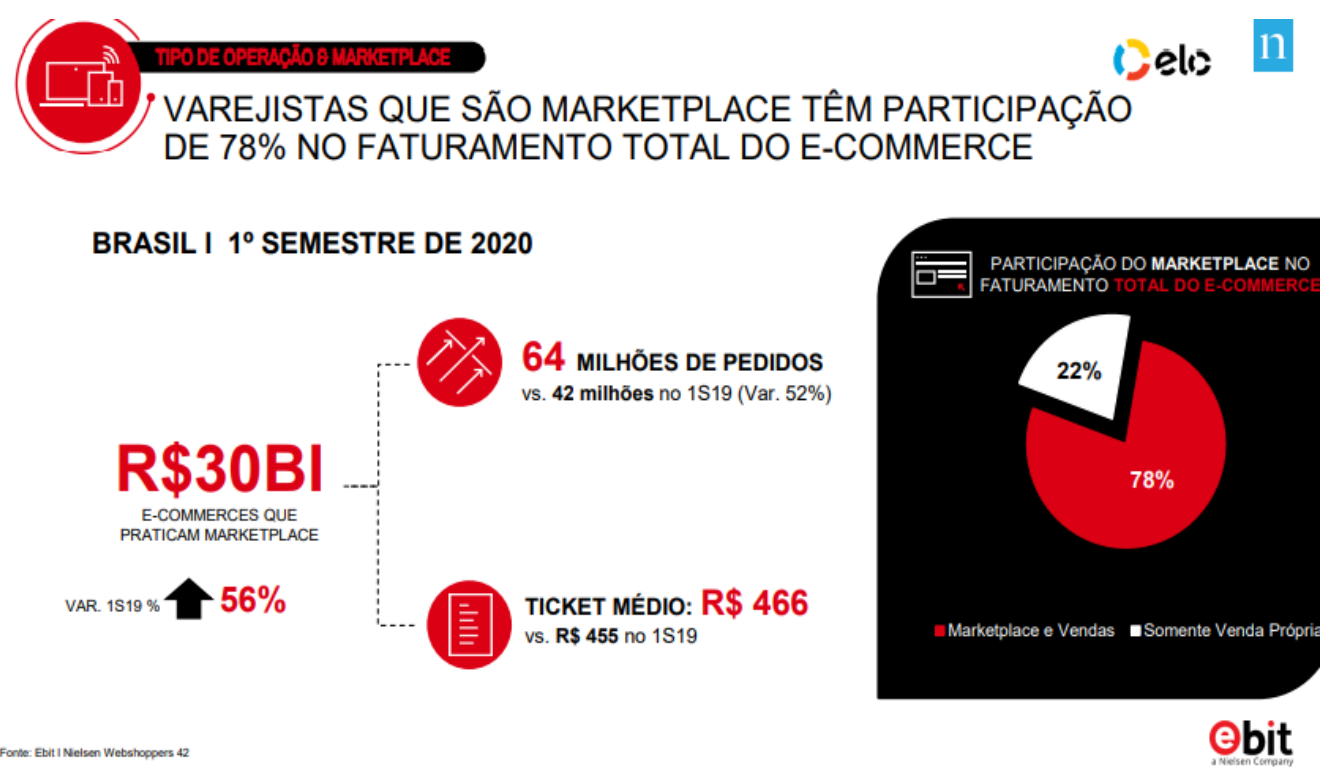

Fonte: Ebit/Nielsen

\subsection{Marketplace durante a pandemia}

A pandemia do SARS-Cov2 trouxe uma "onda" de faturamento para os marketplaces, visto que com o isolamento social, as pessoas tiveram muito mais tempo livre. Como a maioria dessas pessoas gastou esse tempo na internet, é possível dizer que isso tenha feito com que elas se sentissem mais à vontade para comprar online, o que fez com que os vendedores que vissem suas vendas dispararem. Segundo dados de pesquisas recentes, o comportamento de compras online fará parte, daqui para frente, do cotidiano de brasileiros. "O Brasil registrou um aumento médio de $400 \%$ no número de lojas que abriram o comércio eletrônico por mês durante o período da quarentena" (ISTO É, 2020).

AUMENTO DAS COMPRAS ONLINE: $61 \%$ dos (consumidores entrevistados pelo estudo "Novos hábitos Digitais em tempos de covid-19") que já compraram por meios digitais afirmam ter aumentado suas compras online devido ao isolamento social. Esse aumento representa $50 \%$ a mais em 
compras online para $46 \%$ dos respondentes. Além disso, $79 \%$ compraram comida/ bebida para consumo imediato (por delivery) e também afirmam ter aumentado em $50 \%$ seus pedidos ( $44 \%$ dos entrevistados). (SBVC, 2020)

No início da pandemia, mais especificamente dos dias 23 a 29 de abril de 2020, a Sociedade Brasileira de Varejo e Consumo, realizou uma pesquisa com 1000 entrevistados, no qual, entre outras conclusões, apresentou que o varejo não voltará ao que era antes da crise, pois os consumidores estão adotando hábitos digitais e pretendem mantê-los após o fim da pandemia. Junto a isso também concluíram que o consumidor brasileiro tem apresentado um novo comportamento, haja vista que dos 92\% dos entrevistados que já realizaram compras online, $8 \%$ fizeram sua primeira compra via e-commerce durante o período de quarentena. Dentre os segmentos desse setor de comércio, se destacam os marketplaces, como demonstra o relatório da $42^{\mathrm{a}}$ edição do Webshoppers:

(...) ० e-commerce brasileiro ainda é bastante dependente dos marketplaces. De acordo com a pesquisa, os varejistas destas plataformas têm participação de $78 \%$ no faturamento total do mercado. O crescimento do setor com a pandemia é perceptível nos números: $\mathrm{R} \$ 30$ bilhões do faturamento dos seis primeiros meses de 2020 são de lojas que praticam marketplaces, uma expansão de 56\% sobre o mesmo período de 2019. (E-COMMERCE, 2020).

E, a partir do contexto da pandemia, o e-commerce se estabelece como a modalidade de preferência dos consumidores, em um futuro cenário de recuperação econômica para o país e para o mundo. Isso porque, mesmo em mesmo em uma conjuntura de crise econômica derivada da crise de saúde pública, o serviço prosperou.

Apesar das consequências terríveis dessa pandemia, o momento abriu uma oportunidade às plataformas de vendas. Elas podem se consolidar e fidelizar os consumidores tardios e atuar em um mercado muito mais amplo e maduro após a crise. Agora, com a reabertura iminente do comércio e a base de consumidores ampliada, é preciso trabalhar na frequência e fidelização desses clientes. Isso pode ser por meio do oferecimento de um serviço rápido, conveniente e acessível - de forma que se estabeleça um hábito que poderá perdurar por muito e muito tempo (NICOLAU, 2020). 
A Figura 6 demonstra, por meio de dados recentes, como as vendas cresceram durante a pandemia, o que por sua vez, revela como essa tendência parece estar se estabelecendo firmemente no mercado brasileiro. 
Figura 6: Recorde no E-commerce

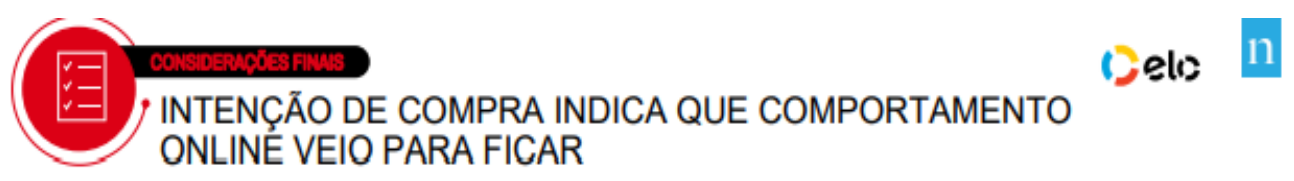

\section{INTENÇÃO DE COMPRA NA INTERNET}

Você pretende comprar alguma categoria de produtos nos próximos três meses pela Internet?

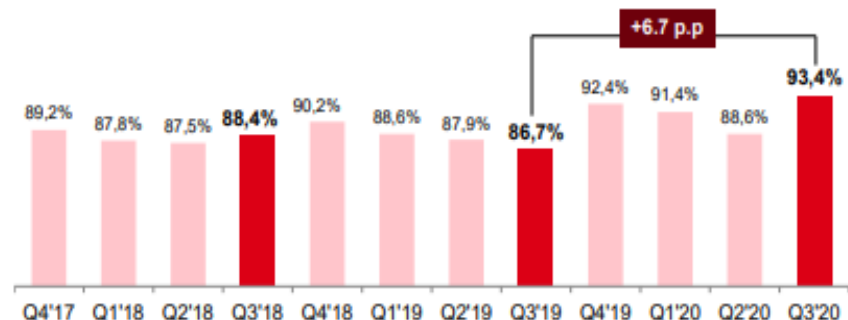

$$
\begin{array}{r}
\text { Para algumas categorias, o } \\
\text { crescimento chega a ser } \\
\text { 4x o aumento da intenção } \\
\text { de compra (vs Q'19) }
\end{array}
$$

$\begin{array}{llllllllllll}\text { Q4'17 } & \text { Q1'18 } & \text { Q2'18 } & \text { Q3'18 } & \text { Q4'18 } & \text { Q1'19 } & \text { Q2'19 } & \text { Q3'19 } & \text { Q4'19 } & \text { Q1'20 } & \text { Q220 } & \text { Q3'20 }\end{array}$

\section{ebit}

Fonte: Ebit/Nielsen 


\section{REFERÊNCIAL TEÓRICO}

O capítulo a seguir irá apresentar o referencial teórico do estudo. Para cumprir essa função, ele estará dividido em três partes: a primeira trata sobre o comportamento do consumidor, contextualizando do que se trata, sua importância e mudanças, ao longo do tempo. Por sua vez, a parte dois diz respeito à percepção do consumidor, como ele se relaciona com a marca. E, por fim, a terceira fala sobre as atitudes do consumidor.

\subsection{O que é o comportamento do consumidor e qual sua importância?}

Solomon (2016, p.6) define o comportamento do consumidor como o "(...) estudo dos processos envolvidos na seleção, compra, uso ou descarte de produtos, serviços e ideias que satisfazem necessidades e desejos.".

O comportamento do consumidor, ainda segundo o autor, abrange um campo de estudos que envolve seleção, compra, uso ou descarte de produtos, serviços que satisfaçam necessidade e desejos dos indivíduos ou grupos. E nesse processo há muitas variantes envolvidas, como os fatores de influência, por exemplo, que delimitam tanto os gostos desses clientes quanto a oferta e disponibilidade de produtos no local onde eles se encontram.

Dessa maneira, o consumidor tem seu comportamento moldado em função da sociedade na qual se encontra. Um caso prático de como isso se dá é a própria adolescência. Nos grupos de adolescentes, em geral, percebe-se que cada agrupamento é formado por jovens que se identificam uns com os outros por conta de seus gostos e comportamentos parecidos. Talvez por serem tão semelhantes entre si, esses jovens são extremamente críticos e julgam os outros, e a eles próprios, muito severamente. Se alguém do grupo destoar em algo, vestir algo muito diferente, ou tiver ideias diversas, essa pessoa provavelmente será alvo de comentários, brincadeiras e, em casos mais sérios, bullying. 
Uma vez que estão sob influência direta uns dos outros, esses adolescentes são levados, por seus próprios pares, a escolherem produtos e serviços de uma maneira muito mais crítica do que fariam se estivessem sozinhos. Então, não é difícil perceber como fatores internos e externos têm peso considerável na escolha de um produto pelo consumidor. Influências gerais como internet, televisão, cinema e aspectos culturais, no geral, fazem com o que o consumidor sinta impelido a consumir o que ver e também servem como um grande espelho para essas pessoas. Dessa forma, quando um cliente encontra uma pessoa ou grupo que sirva de fonte de inspiração, ele vai buscar consumir, continuamente, produtos que lembrem essa personalidade, pois, de alguma maneira, ele quer ser visto e entendido da mesma forma com que o motivo de sua admiração é. Solomon (2016, p.79) diz que a cultura é a personalidade de uma sociedade.

Hoje em dia, ainda que o mundo seja extremamente globalizado, não há como definir uma "cultura geral", apesar de existirem, por exemplo, muitas pessoas que apreciem determinada música, estilo de roupa etc. É possível dizer que o termo "cultura de massa" está perto de ser superado, haja visto a pluralidade de gostos, estilos, subestilos e novas tendências que diariamente surgem ao redor de todo o mundo.

A internet propiciou a rápida troca de informações, o compartilhamento instantâneo de pensamentos, ideias, moda, dentre outros, que permite que infinitas culturas coexistam no mesmo local. É difícil regrar o comportamento do consumidor, uma vez que cada ser humano é único e extremamente subjetivo. Por mais que existam dados, pesquisas e estudos voltados para a análise das emoções humanas e transformação desses dados em padrões, é preciso entender como os consumidores se entendem diante do ato de consumir.

Enquanto alguém pode querer adquirir um relógio de parede somente pela sua funcionalidade em mostrar as horas, outros podem querê-lo não por sua função, mas porque o relógio é um bom elemento decorativo, ou porque ele traz memórias da infância ou somente porque ele é bonito. As pessoas são, em seu âmago, um mar de subjetividade, e o estudo do comportamento humano não traz respostas $100 \%$ objetivas, sendo que sempre haverá alguma característica que diferenciará uma pessoa da outra. Mesmo interessados nas mesmas coisas, nem sempre os 
consumidores irão agir e se comportar da mesma forma, e isso exige uma grande atenção por parte de cada uma das marcas que desejam ser conhecidas e amadas.

Para as empresas, em específico, é fundamental que elas consigam conhecer seus consumidores da melhor maneira possível, para que possam estudar diferentes formas de tentar atender ao máximo suas expectativas e garantir que eles sejam fiéis a elas. Voltando ao exemplo do relógio, uma loja que vende este tipo de produto sabe que seu público não é único, mas sim muito diverso. Então, para atender essa gama de clientes, é ideal que o serviço ofereça diferentes relógios a diferentes preços, para que possa agradar tanto o cliente que busca por algo decorativo quanto aquele que deseja um aparelho funcional.

Sobre a relação dessa subjetividade do consumidor com seu comportamento, Solomon faz o seguinte comentário:

A perspectiva dramatúrgica sobre comportamento do consumidor vê as pessoas como atores que representam diferentes papéis. Todos nós representamos vários papéis e temos nossos próprios roteiros, acessórios e figurinos. (SOLOMON, 2016, p.253).

Conhecer o comportamento do consumidor não é sobre saber especificamente qual o gosto de cada cliente, mas, entender, no geral, o que mais agrada o públicoalvo, qual é o produto mais procurado, qual é a principal razão pela qual o produto é desejado e adquirido, qual é o diferencial diante das concorrentes, entre outros. Conhecendo o consumidor, o dono da loja de relógios poderá prever qual seu será seu comportamento quando lançar uma nova coleção e qual produto vai ou não atrair a atenção do consumidor. É assim que aumenta a probabilidade da loja ter clientes fiéis, já que o cliente se sente único e o comerciante tem sempre a oportunidade de continuar vendendo.

Os pesquisadores continuam identificando fatores que polarizam nossas decisões - e muitos deles são fatores que operam abaixo do limiar de percepção consciente. Em um estudo, as atitudes dos respondentes em 
relação a um produto indesejável - grilos ao Curry! - melhoraram quando eles foram solicitados a se aproximar. Esse movimento físico normalmente está associado a gostar; mesmo os movimentos de nosso corpo ou outras reações fisiológicas podem influenciar o que ocorre em nossa mente. (SOLOMON, 2016, p.59)

Depreende-se, então, que entender o que é o comportamento do consumidor é muito importante para uma empresa, pois permite que ela se antecipe e dê ao cliente exatamente o que eles esperam, fazendo-o sentir especial e importante para a empresa.

\subsection{Mudança de comportamento do consumidor e influências}

Os consumidores atuais mostram-se cada vez mais críticos, já que possuem a facilidade para acessar de forma rápida comparativos de preços. Hoje, os clientes pesquisam mais antes de fechar negócio.

Como o consumidor começou a ver preço, prazo e informações dos produtos, em vez de se importar somente com a marca da loja, os pequenos passaram a ter oportunidades no comércio eletrônico. $O$ consumidor não comprava mais pelo nome da loja, e sim pelo produto. (SALVADOR,2013, p. 12)

Essa expansão é decorrente também da massificação no uso de dispositivos móveis, que permitem facilidade de acesso à internet em qualquer lugar que o usuário esteja (LOPES,2020). Dessa maneira, as buscas por compras online e o consumo virtual, em geral, cresceram de forma exponencial, abrindo caminho para que o mercado de marketplace, por exemplo, se implantasse no país. Seria o que definiu SALVADOR (2013, p.12) "Com a massificação dos contratos de consumo, assim como o uso da internet como meio mercadológico, surge a inovação: o Marketplace".

Com isso, o protagonista, quando se diz respeito ao consumo, mudou: atualmente é o consumidor que dita as regras da venda e não as lojas, pois, com apenas um clique, ele tem a possibilidade de saber quais são as vantagens de cada compra e, dentre elas, a que mais se sobressai. Saber 0 que influencia 0 
comportamento do consumidor faz toda diferença no processo de criação do marketing de uma empresa, como já falado. Nesse sentido, entender quais são as variáveis que podem influenciar esse comportamento torna o processo ainda mais individualizado, fazendo com que o consumidor se sinta especial.

Bem-vindo à nova era do marketing sensorial, em que as empresas refletem cuidadosamente a respeito do impacto das sensações sobre nossas experiências com o produto. Dos hotéis e fabricantes de automóveis às cervejarias, as empresas percebem que nossos sentidos nos ajudam a decidir quais produtos nos atraem - e quais deles se destacam dentre inúmeras opções semelhantes no mercado. (SOLOMON, 2016, p.175).

O consumidor, ao escolher o produto, leva em conta muitos fatores, como idade, local de trabalho, experiências anteriores, o que as pessoas ao seu redor têm a opinar, dentro outros, comprovando, novamente, como o ambiente externo exerce enorme influência em seu comportamento. Ademais, é importante ressaltar a relevância que a influência interna de cada consumidor exerce sobre ele.

As emoções que teve ao ver determinado produto, qual sua motivação pessoal para adquirir aquela compra, satisfação própria, e muitos outros aspectos subjetivos e particulares acabam por guiar o consumidor em meio a grande variedade de opções que possui. Portanto, não há como racionalizar ou definir um padrão. Essas emoções, geralmente, são usadas como estratégia de venda pelo Marketing das empresas, que tenta atrair o consumidor não pela funcionalidade do produto, mas sim pela emoção que a compra dele vai gerar no cliente.

Tudo isso, pois, se resume ao que Solomon expôs como:

As mensagens as quais escolhemos prestar atenção com frequência acabam sendo diferentes do que seus patrocinadores pretendiam que fossem, na medida em que cada um acrescenta sua "visão" às coisas ao atribuir significados que são coerentes com suas próprias experiências, impressões e desejos. (SOLOMON, 2016, p.174).

\subsection{Percepção do Consumidor}


Para Solomon (2016, p.174), a percepção é o processo no qual as pessoas selecionam, organizam e interpretam suas sensações e, ao seu ver, sensação é a resposta imediata dos receptores sensoriais do corpo, como nariz, boca, ouvido, entre outros, e também a estímulos básicos do cotidiano como cor, som, luz, texturas e odores. Numa linha geral, estudar a percepção seria entender os acréscimos que se dá às sensações para que elas tenham significado.

A definição de trabalha dois campos de sentido em um só: percepção e sensação, que coexistem em perfeita harmonia. Dessa maneira, tem sido cada vez mais comum observar as empresas optarem por causar emoções positivas em seus clientes. Ao oferecerem um produto diferenciado, criado para trazer à tona os melhores sentimentos, mesmo que ele tenha somente alguma funcionalidade básica, o despertar de uma boa emoção fará com que os clientes tenham uma ótima percepção daquele produto e, conscientemente ou não, atribuirão a ele uma boa avaliação - o que conta muito para as empresas. Por sua vez, na visão de Schiffman (2005, p.02), percepção se refere ao produto dos processos psicológicos, em que contexto, julgamento, experiência passada, relações e memória desempenham um papel nesses processos.

Assim, pode-se entender que a percepção de mundo se refere às experiências particulares do indivíduo pelos diversos ambientes que passa ao longo de sua trajetória, de tal forma que cada ser humano irá perceber o meio em que está de forma diversa. Mesmo que coexistam 400 pessoas, centradas em um mesmo local, enxergando e vivendo as mesmas coisas, 400 percepções diferentes nascerão, haja visto que a unicidade e peculiaridades humanas implicam em experiências passadas e processos psicológicos singulares. Assim como Schiffman (2005), Solomon (2016) também propôs que as experiências são únicas, mas, analisando de forma superficial, pode-se considerar que, enquanto Schiffman partiu para uma análise mais subjetiva, Solomon prefere desenvolver uma análise mais biológica do que é a percepção humana.

Entende-se, então, que a percepção humana é única e exclusiva de cada ser. Para o mesmo objeto, podem existir inúmeras percepções. Assim, um consumidor que analisa um produto para sua compra pode ter muitas sensações geradas pelo modo como enxergou e percebeu aquele produto. Dessa maneira, nenhuma empresa gerará 
a mesma sensação em todos seus clientes, mas ela pode tentar buscar algo que desperte, na maioria deles, emoções positivas, como felicidade e esperança.

Finalmente, estudamos a sensação e a percepção porque são tópicos intrinsecamente interessantes que nos ajudam a responder a questões básicas relativas à nossa existência diária, especialmente como vemos, ouvimos, sentimos o gosto e usamos os outros sentidos. Está claro que possuímos um arsenal impressionante de equipamento sensorial, cujo funcionamento nos fornece uma quantidade espantosa de informações sobre o mundo físico. (Schiffman, 2005, p.03).

Destarte, entender, no geral, como funciona a percepção humana é importante para que se saiba como ofertar determinados produtos e também como tentar despertar boas sensações nos consumidores, que farão com que uma percepção positiva do produto nasça, cresça e seja compartilhada mundo afora. Assim, as empresas começam a entender que determinadas cores, cheiros, texturas, ambientes, sons etc., poderão atrair e fidelizar mais clientes. Tudo tem influência em como o consumidor perceberá a sua futura compra e as companhias que perceberem isso prematuramente terão uma grande chance de sair na frente de suas concorrentes.

Por fim, mesmo que, a princípio, a percepção de um cliente não seja exatamente a esperada, ela pode ser mudada ao longo do tempo, através do estímulo de sensações agradáveis e positivas. Ter consciência de sua importância faz com que a organização particularize mais seus clientes, enxergando-os de forma individual e ofertando tratamentos mais profícuos.

\subsection{Atitude do consumidor}

A atitude, em linhas gerais, significa o modo de agir ou até mesmo reagir de alguém, a maneira de se portar, a ação de uma pessoa frente a uma situação, dentre outros. Em geral, ela serve para exteriorizar os valores dos indivíduos e suas características, exemplo, se uma pessoa tem como valor a solidariedade e é como caracterizada como tímida, suas atitudes demonstrarão isso, talvez ela não seja líder de grandes mutirões de ajuda, mas no seu dia a dia, poderá, por exemplo, ajudar 
pessoas em situação de rua. E as atitudes são importantes para que as coisas fluam na prática, pois diz respeito a tomada de ações.

Solomon (2016, p.301) descreveu atitude como sendo uma avaliação duradoura e genérica sobre todas as pessoas, inclusive nós, sobre também anúncios ou problemas. É genérica, porque serve para qualquer situação e duradoura porque acompanha a vida de todos. Pode-se compreender que a atitude reflete sobre 0 comportamento do indivíduo e sobre seus valores, uma vez que age como a forma que o interior humano tem de se externalizar e materializar-se em uma ação.

Como disse Solomon, pode-se entender que a atitude reflete sobre 0 comportamento do indivíduo e seus valores, é uma forma de seu lado interno se externalizar e materializar-se em uma ação: a atitude. Com isso, as pessoas ao redor só avaliam o final desse processo, que é a ação, em si, mas não o que levou até ela. No caso desse último, é então, compreendido por quem estuda as atitudes das pessoas. No comércio, é importante aos que desejam obter sucesso com vendas, entender o que gera as atitudes de seus clientes para consumir determinados produtos, pois, então, saberá o que deve fazer para convencê-lo a comprar;

O psicólogo Daniel Katz desenvolveu a teoria funcional das atitudes para explicar como as atitudes facilitam o comportamento social. De acordo com essa abordagem pragmática, as atitudes existem porque desempenham alguma função para a pessoa. Os consumidores que esperam precisar lidar com situações semelhantes no futuro são mais propensos a formar atitudes antecipadamente. Duas pessoas podem ter uma atitude perante um objeto por motivos bastante distintos. Por isso, pode ser útil para as empresas saber por que uma atitude é mantida antes de tentar modificá-lá. (SOLOMON, 2016, p. 302)

É importante que as empresas entendam quem é o seu consumidor para conseguir, em linhas gerais, prever o comportamento que ele terá. Mas, obviamente, não há como excluir determinantes internos e externos que podem influenciar na atitude desses. Entenda também o que a atitude que ele tomou representa para ele, por exemplo, o porquê de não ter adquirido um produto na loja $x$, mas sim na $y$, às vezes por um valor até mais alto.

Solomon (2016) aborda esse assunto na seguinte perspectiva: 
Persuasão se refere a uma tentativa de mudar as atitudes dos consumidores. O modelo de comunicação especifica os elementos que as empresas precisam para transmitir significado. Esses elementos são fonte, mensagem, meio, receptor e feedback. (SOLOMON, 2016, p.337)

Portanto, as atitudes ajudarão a definir o perfil do consumidor. Uma vantagem importante aos lojistas e comerciantes é que as atitudes podem ser mudadas e moldadas também, dependendo do interesse em questão. Entretanto, é de grande valia que se entenda sobre as atitudes, buscando conhecer os consumidores para que possam tratá-los de forma mais exclusiva e buscando uma possível fidelização deles. 


\section{MÉTODO DO ESTUDO}

O presente capítulo aborda o método utilizado neste trabalho. Dessa forma será explicado o tipo de pesquisa realizado, como foi feita a seleção dos entrevistados, o procedimento da coleta de dados, a análise deles e, por fim, quais as limitações apresentadas.

\subsection{Tipo de pesquisa}

Como o objetivo deste trabalho é em entender mais sobre o tema pesquisado, foi realizada uma pesquisa do tipo exploratória e qualitativa. Segundo Piovesan e Temporini (1995, p.321), “A pesquisa exploratória tem por finalidade o refinamento dos dados da pesquisa e o desenvolvimento e apuro das hipóteses, nesta nova concepção é realizada com a finalidade precípua de corrigir o viés do pesquisador e, assim, aumentar o grau de objetividade da própria pesquisa, tornando-a mais consentânea com a realidade."

Por outro lado, a pesquisa qualitativa gera conhecimentos mais profundos sobre indivíduos, de forma a facilitar o entendimento sobre seus pensamentos a respeito de um fenômeno (DIAS, 2000).

\subsection{Seleção dos entrevistados}

Para a realização da pesquisa, foram selecionadas 12 pessoas com perfis divididos em quatro grupos: mulher estudante, homem estudante, mulher graduada e homem graduado. A seguir, apresenta-se uma tabela com descrição do perfil dos respondentes. 
Tabela 1: Perfil dos entrevistados.

\begin{tabular}{|c|c|c|c|c|c|}
\hline Entrevistada(o) & Nome & Gênero & Idade & Escolaridade & $\begin{array}{l}\text { Sabe o que é } \\
\text { Marketplace? }\end{array}$ \\
\hline 1 & Camille & Feminino & 21 & Estudante & Não, não sei. \\
\hline 2 & Alberto & Masculino & 51 & Empresário & Sim. \\
\hline 3 & Raphaela & Feminino & 22 & Estudante & Acho que sim. \\
\hline 4 & Beatriz & Feminino & 71 & Historiadora & Sim. \\
\hline 5 & Betty & Feminino & 45 & Administradora & Sim. \\
\hline 6 & Giulia & Feminino & 21 & Estudante & Sei "por alto". \\
\hline 7 & Gabriel & Masculino & 19 & Estudante & Sim. \\
\hline 8 & Priscila & Feminino & 21 & Estudante & Sei. \\
\hline 9 & Henry & Masculino & 74 & Químico & Não. \\
\hline 10 & Caroline & Feminino & 21 & Estudante & Não. \\
\hline
\end{tabular}




\begin{tabular}{|l|l|l|l|l|l|}
\hline 11 & Stella & Feminino & 22 & Estudante & Não. \\
\hline \hline 12 & Fernanda & Feminino & 21 & Estudante & Não. \\
\hline
\end{tabular}

\subsection{Coleta dos dados}

A coleta de dados ocorreu por meio de entrevistas em profundidade com os entrevistados. Para guiar as entrevistas, utilizou-se um roteiro, disponível no Apêndice 1. A pesquisa foi iniciada com a coleta de dados pessoais. Em seguida, perguntou-se sobre conhecimento em relação ao que é um marketplace e se o entrevistado já havia consumido dessa plataforma. Por fim, para concluir, foi apresentado um dado sobre a plataforma Mercado Livre, empresa argentina de tecnologia e soluçõe, e feita algumas perguntas com o site aberto na página inicial desse marketplace.

O Mercado Livre foi escolhido neste estudo quantitativo por ser o maior marketplace da América Latina e por sua importância na economia brasileira: existem atualmente 15.480 vendedores com faturamento que permite sustentar 98.648 postos de trabalho, o que representa uma fatia de $0,12 \%$ do Produto Interno Bruto (PIB) do Brasil. E, somente no Brasil, o MercadoLivre.com é o quinto site mais acessado da Internet, com cerca de 52 milhões de visitantes únicos por mês, segundo estudo da ComScore de janeiro de 2018. Além disso, é o maior site de comércio eletrônico do Brasil.

Enquanto eram feitas as entrevistas, os entrevistados eram incentivados a entrar na plataforma do Mercado Livre e navegar por ela. Isso facilitou aos entrevistados conseguirem responder as perguntas do roteiro de maneira mais precisa, pois não precisariam ficar lembrando do site para saberem o que responder. 
Todas as entrevistas foram realizadas no mês de novembro de 2020, presencialmente, tomando os devidos cuidados sanitários. Para se obter dados fiéis, as entrevistas foram registradas em gravações de áudio, com consentimento dos participantes.

\subsection{Tratamento dos Dados}

Após a finalização das entrevistas, o tratamento dos dados foi feito a partir da transcrição integral de todas as gravações de áudio, pela autora do trabalho. Dessa maneira, pode-se fazer a análise, comparação e conclusões das falas dos participantes a respeito do tema da presente pesquisa e, a posteriori, o desenvolvimento do capítulo 5 , no qual consta a análise dos dados.

\subsection{Limitações do método}

O método usado conta com a participação de um grupo de pessoas pequeno, escolhidos pela autora deste trabalho, e, no âmbito dessa pesquisa, próximos a ela, portanto, pode apresentar carga tendenciosa nas respostas.

Ademais, as perguntas abertas podem influenciar as respostas dos participantes, dependendo da forma como são feitas. O viés interpretativo de análise dos dados coletados por parte da pesquisadora também pode influenciar no resultado.

Outra limitação é que todos os respondentes têm acesso à internet e à educação, ou seja, não representam de forma fidelizada o retrato da população brasileira. E, por fim, só foi mostrado a eles um site de marketplace, no caso, do Mercado Livre, portanto, os que não tinham muito contato com esse nicho se respaldaram apenas nesse único exemplo. 


\section{ANÁLISE DOS DADOS}

Este capítulo irá apresentar a análise e discussão dos dados presentes na entrevista realizada. Para essa finalidade, será dividido em três partes: uma análise geral da primeira parte do roteiro de entrevistas; seguida da percepção dos consumidores frente ao site Mercado livre; e, por fim, a atitude desses também em relação ao marketplace já mencionado.

\subsection{Visão geral sobre conhecimento de marketplaces}

No primeiro momento da entrevista, os entrevistados foram questionados a respeito de um possível conhecimento prévio sobre a definição de marketplace, sendo que, dos 12 entrevistados, apenas alguns afirmaram que sabem o que significa essa modalidade do comércio eletrônico. Com base nisso, um fator interessante é que, após a explicação do significado de marketplace e da citação de nomes de grandes empresas do ramo, parte dos respondentes mudava de postura e diziam saber, então, o que significava.

Após esta etapa, os entrevistados foram, então, indagados sobre compras na plataforma marketplace, se já haviam realizado e, caso positivo, se elas eram recorrentes ou não. Todos, inclusive as pessoas que disseram não saber o significado de marketplace, responderam que sim, confirmando a realização de compras anteriores na plataforma.

Essa mudança de postura demonstra como esse comércio já está popularizado na sociedade, mesmo que o nome, talvez por ser estrangeiro, não seja de conhecimento de todos. E o fator de conhecimento não está atrelado à faixa etária, gênero ou condição de escolaridade, pois as respostas de todos os perfis de públicos foram variada, sem influência em suas respostas. 
Um fator interessante é que, dentre os entrevistados, há duas pessoas que trabalham em marketplaces, e os dois vendem produtos nessa plataforma. Um deles afirmou que: "Eu tenho uma empresa na qual eu trabalho com vários marketplaces, os grandes marketplaces, e eu vendo por lá meus produtos, que são relógios e é um sucesso. Com a pandemia, teve um crescimento" (Alberto).

Por fim, mesmo sem saber que a plataforma de vendas se chamava marketplace, todos os entrevistados já foram expostos a ela e tiveram acesso a algum modelo que a replique. Solomon (2016) diz que uma das estratégias de marketing atualmente é a prioridade de construção de relacionamento com os clientes e, mesmo que esses relacionamentos variem quanto à sua origem, os laços criados podem ajudar na compreensão de alguns dos possíveis significados que os produtos têm para os clientes. Assim sendo, mesmo que a pessoa não saiba que aquele comércio se chama marketplace, ela, por exemplo, pode associar que todos os websites daquele modelo são mais baratos e vantajosos de acessar, uma vez que também possuem comparativo de preço.

\subsection{Percepção dos consumidores sobre o Mercado Livre}

Após familiarizar cada convidado com o termo marketplace, foi analisado a percepção desses em relação ao website do Mercado Livre. Dessa forma, a autora leu um dado a respeito dessa plataforma e acessou, junto com o participante, a página inicial do site em questão.

Em geral, o que mais chama a atenção dos consumidores do Mercado Livre é a variedade de produtos, seguida de perto pela cor, no caso do logotipo, amarela. Também foram citadas a facilidade de acesso no website, que possui formato bastante prático para achar o que se precisa, e, agilidade. Ademais, um dos entrevistados também mencionou que a personalização exibida na parte superior do website, onde uma mensagem de boas-vindas seguida do nome do consumidor pode ser vista, ajuda a invocar um sentimento de proximidade e ligação com a marca. 
O fato de o amarelo chamar atenção do cliente também se refere ao que Solomon (2016, p.177) pontua:

Hoje sabemos que as percepções de uma cor dependem de seu comprimento de onda físico e do modo como a mente reage aos estímulos. O amarelo se situa no meio dos comprimentos de onda detectáveis pelo olho humano e, por isso, é a cor mais brilhante e atrai a atenção. Os guias telefônicos são amarelos para aumentar o nível de atenção de telefonistas entediados.

Outrossim, ao lembrar do Mercado Livre, os consumidores fazem associações subjetivas em geral relacionadas aos produtos que costumam consumir. Dentre as respostas está, novamente, a variedade de produtos, de lojas, e, até mesmo, de preço. Além disso, os entrevistados também citaram como características positivas a agilidade de entrega, a existência de produtos novos/usados e a presença de itens de variados departamentos, desde mercadorias básicas à construção civil.

Nesse contexto, quando questionados quanto ao que associam como foco de vendas do Mercado Livre, a maioria dos entrevistados citou produtos advindos diretamente de experiências anteriores e particulares com a plataforma. Para Schiffman e Kanuk (2009, p.118), cada ser humano possui necessidades que o motivam a comprar, tais como a autorrealização, necessidades sociais e fisiológicas, assim como a percepção e atitudes no comportamento da compra. Portanto, é notório como as visões e observações de cada pessoa variam conforme seu interesse:

Suplementos, equipamentos de academia. Principalmente na época da quarentena, entrei bastante para procurar aparelhos desse tipo, acho que não só eu como muitas outras pessoas (Camille).

Nossa, tudo. Desde coisas para a casa, quando estava fazendo obras, minha luva de muay thai, coisas para natação e até chocolate, minha irmã já comprou (Raphaela).

Todos, presentes para netos, utensílios domésticos (Beatriz). 
E, por fim, a maioria dos consumidores disse já ter observado anúncios do Mercado Livre em outros websites que acessaram, em suas redes sociais e afins. Dessa forma, supõe-se que esse é um marketing efetivo da empresa, visto que mesmo os consumidores que não sabiam na teoria o que é marketplace, eles associaram rapidamente o possível significado da palavra assim que ouviram o nome Mercado Livre, pois já tiveram contato com ele em algum momento.

\subsection{Atitude dos consumidores sobre o Mercado Livre}

Ao analisar as atitudes dos consumidores quanto ao marketplace do Mercado Livre, é possível fazer algumas inferências: entrevistados mais velhos preferem comprar presencialmente por não estarem totalmente adaptadas com o mundo digital e também por possuírem atendimento diferencial no comércio físico: "Prefiro muito mais presencialmente, porque eu tenho uma idade mais avançada, então vou no preferencial" (Beatriz). Dessa forma, o ato de fazer compras presencialmente pode ser visto, como pontua Solomon (2016, p. 358), também como uma experiência de compra motivada pela atração interpessoal, ou seja, para os clientes com mais idade, ao oferecer $\mathrm{o}$ atendimento preferencial e personalizado, o ambiente de compra presencial parece mais seguro e supervisionado do que o on-line.

Nesse contexto, as respostas foram variadas, desde pessoas que preferem, com certeza, comprar online, até outros que só estão comprando online por uma necessidade maior, surgida diretamente da pandemia do novo Coronavírus. Porém, um elemento foi comum em várias respostas: o fato de que comprar vestuário pelo marketplace ainda deixa os consumidores em dúvida. Essa situação pode se dar por conta da variação de tamanho que um produto exibe virtual e fisicamente, o que impede o consumidor de saber o caimento, tamanho e conforto da roupa, além de ceifar seu direito de avaliar a qualidade do produto. Outro motivo interessante é que os consumidores preferem comprar roupas fisicamente de modo a evitar toda a burocracia que as plataformas os obrigam a passar caso uma roupa comprada virtualmente precise ser trocada: 
Incomparável. Hoje em dia, a gente já está acostumado a comprar pelos marketplaces, só vou na loja quando eu preciso ver o produto na mão ou experimentar. Mas, normalmente, o que eu não preciso experimentar ou ver o produto, porque eu já conheço, eu já compro pelo marketplace e, principalmente, pelo Mercado Livre, que eu considero o melhor para comprar (Alberto).

Tirando roupas e calçados, eu prefiro comprar pela internet. Roupas e calçados eu ainda compro bastante em lojas físicas (Betty).

Prefiro presencial, mas nessa pandemia, o jeito é online (Stella).

Pela confiança do produto: lojas físicas. Mas pela praticidade: Iojas online (Fernanda).

Ademais, ao ser questionado sobre ser relevante o problema de não conseguir experimentar os vestuários quando compra pelo marketplace, o participante respondeu:

São muito poucos itens que você não consegue comprar pela internet e, hoje em dia, tem essa vantagem de, no Mercado Livre, se em uma semana você não gostar do produto, você pode devolver. Então você compra, experimenta, se por acaso ficou pequeno, ficou grande, não era o que você esperava, você "mete" no Correios de volta, que chega lá, eles estornam na mesma hora, porque o mercado pago deles é muito bom (Alberto).

Outro entrevistado também respondeu que, por questões de preços, já experimentou fisicamente o produto, mas finalizou a compra online.

Eu já comprei online, mas a maioria das vezes eu compro física, mas têm vezes que estava melhor comprar online que eu experimentei fisicamente, mas comprei online. (...). Pela facilidade e pelo número de promoções online que eu percebo (Gabriel).

Outrossim, é possível perceber que a maior parte dos consumidores já realizou compras pelo marketplace Mercado Livre e dizem gostar do site. E, nesse sentido, também consideram o site intuitivo e de fácil navegação, achando rapidamente o produto que desejam e com uma grande variedade de preços. Dessa forma, há a presença de um comportamento chamado por Solomon (2016, p. 359) de 
showrooming, ou seja, o consumidor examina as lojas presenciais de modo a examina as opções de preço, e logo depois encontram e compram o mesmo produto on-line por um valor mais baixo. Segundo os entrevistados:

Super fácil. Ele te responde tudo, você clica ali, ele já vai te dando o andamento. Sem dificuldade nenhuma, tive que cancelar, outro dia, uma compra foi super simples de fazer o cancelamento, tudo muito simples (Alberto)

Sim, acho que basta colocar o nome e a marca do produto, já vêm várias empresas que vendem esse produto (Betty)

Sim, além de achar uma plataforma de fácil acesso, como eu disse antes, tem bastante clareza o site e consegue entender bem as áreas do site (Gabriel)

Acho bastante intuitiva. Geralmente entro focada no que quero, então não sou levada para comprar outros produtos. Mas acho muito bom todo o processo de compra (Fernanda).

Por fim, foi perguntado a cada um dos participantes sua opinião a respeito do design e das cores do site. As opiniões foram bem divididas, mas uma coisa é certa: o amarelo do Mercado Livre é uma marca registrada, praticamente, todos citaram essa questão em suas falas.

Eu confesso que a "cor amarela" é uma cor que chama atenção, mas eu não acho legal para um site, mas o design acho bem atualizado (Camila).

Espetacular, adoro. Amo o amarelinho, chama a atenção, gosto de ver aquele amarelinho. Sou fã do Mercado Livre" (Alberto).

Em geral, não há melhorias urgentes para sugerir ao Mercado Livre, segundo os entrevistados. As sugestões de melhorias foram relativas ao contato direto com vendedores, em especial os de itens usados, e também a possibilidade de entrega gratuita e expressa.

Eu acho que uma coisa que me incomoda bastante, é quando você vai comprar uma coisa usada, de uma pessoa física, você não tem contato direto com o vendedor, muitos não colocam telefone, e às vezes postam foto de internet $\mathrm{e}$ não do produto original e não dá para saber como está, de fato, o produto. Isso me incomoda bastante. (Camila) 
Focar mais no contato com o vendedor, mas isso não é algo urgente. Acho a plataforma boa (Caroline).

Eu acho o frete caro, na Amazon Prime, por exemplo, tem o frete grátis e entrega rápida, que é o que me faz querer comprar (Stella).

No mais, a plataforma do marketplace Mercado Livre foi elogiada frequentemente pelos convidados, os quais mostram estar sentindo-se satisfeitos.

Não, por enquanto, eu gostei muito. Fui muito bem atendida. E o Mercado Livre mostra sempre a origem do produto e eu consigo conversar com o fornecedor (Raphaela). 


\section{CONCLUSÃO}

O presente estudo teve como objetivo analisar a percepção e a atitude do consumidor em relação ao marketplace. Para isso, foi realizada uma pesquisa qualitativa, na forma de entrevistas com 12 consumidores que já fizeram compras em marketplaces no Brasil. A partir da análise, chegou-se a algumas considerações finais.

Em um contexto de pandemia viral, um impulso significativo nas vendas digitais é visível, dadas as circunstâncias excepcionais vividas, em que as pessoas precisam, necessariamente, por uma questão de segurança e saúde pública, passar mais tempo em suas casas. Pesquisas já confirmam que o e-commerce veio para ficar, e com a nova realidade vivida, pode ser que não demore muito até que essa modalidade de comércio substitua permanentemente a forma tradicional de compra e venda de mercadorias.

Em relação à pesquisa realizada, nota-se a presença imemorável dos marketplaces nas vidas das pessoas. Empresas de destaque nacional e mundial, como Amazon, Ebay e Mercado Livre, já entendem que se utilizar de artifícios psicológicos ajuda a aumentar o número de consumidores e fideliza-los. A cor amarela em destaque no site do Mercado Livre, por exemplo, é um dos atrativos que mais mexe com os sentidos daqueles que visitam a página na internet.

Todo esse arsenal psíquico deve ser utilizado por aqueles que gerenciam os marketplaces, de modo a atrair e conquistar o consumidor, ganhando-o, primeiramente, através de suas percepções, para, em seguida, amarrá-lo a partir de sua atitude, que passa ser a de descobrir mais sobre o website e começar a efetuar compras. Se a compra for realizada como o esperado, o website ganha mais ainda na fidelidade do cliente, que voltará futuramente para fazer mais compras.

\subsection{Implicações Gerenciais}

Empresas que utilizam os marketplaces devem recorrer a ferramentas que visem conhecer quem é o seu público-alvo/consumidor, aprimorando suas técnicas de 
persuasão e acolhimento quanto a percepção e atitude destes. Assim, ambos saem ganhando: o consumidor, que reconhece a segurança e a eficácia do site e volta mais vezes para comprar, e o vendedor, que ganha um cliente fiel, aumentando ainda mais os seus lucros.

Segundo Solomon (2016, p.361), entre as limitações do comércio eletrônico, para o consumidor, estão a falta de segurança e possibilidade de fraude. Nesse sentido, uma forma de e atrair e fidelizar consumidores é investir em informações e mecanismos de segurança que passem maior confiança ao consumidor, além de garantir-lhe reembolso em caso de falha nesses sistemas.

Além disso, como observado durante as entrevistas, um dos grandes pontos negativos e influentes no processo de compra (especialmente vestuário) é a questão da devolução. Assim, cabe à plataforma em questão oferecer devolução inclusa no frete ou, até mesmo, gratuita. Essa iniciativa atrairia uma gama de clientes que, apesar de já comprarem em marketplaces, ainda tem receio de consumir determinados produtos.

\subsection{Sugestões de futuros estudos}

Como sugestão para uma futura pesquisa, seria interessante que se aumentasse o número de entrevistados, a variedade de classes econômicas, faixas etárias e escolaridade da amostra. Assim, poder-se-ia ter um retrato mais fiel e contundente do cenário brasileiro.

É interessante, também, pesquisar a relação dos consumidores com outros marketplaces nacionalmente conhecidos, para que uma possível comparação a respeito das atitudes e percepções dos clientes destas plataformas seja feita.

Por fim, sugere-se, ainda, que se aumente o número de pesquisas com relação aos marketplaces, visto que ainda é uma área pouco explorada. 


\section{REFERÊNCIAS}

12 Dados que comprovam o crescimento do e-commerce no Brasil. ECOMMERCE BRASIL WEBSITE. Disponível em: https://www.ecommercebrasil.com.br/artigos/12-dados-que-comprovam-o-crescimentodo-e-commerce-no-brasil/. Acesso em: 08 out. 2020.

A era dos marketplaces no brasil. E-COMMERCE BRASIL WEBSITE. Disponível em: <https://www.ecommercebrasil.com.br/artigos/a-era-dos-marketplaces-no-brasil/>. Acesso em: 15 out. 2020

A história do e-commerce no brasil. COM SCHOOL WEBSITE. Disponível em: <https://news.comschool.com.br/a-historia-do-e-commerce-no-brasil/>. Acesso em: 08 out. 2020.

A história do primeiro e-commerce no brasil. COM SCHOOL WEBSITE. Disponível em: https://news.comschool.com.br/historia-primeiro-e-commerce-no-brasil/. Acesso em: 08 out. 2020.

COELHO, Lidiane da Silveira; OLIVEIRA, Rafaela Carvalho; ALMÉRI, Tatiana Martins. O CRESCIMENTO DO E-COMMERCE E OS PROBLEMAS QUE O ACOMPANHAM: a identificação da oportunidade de melhoria em uma rede de comercio eletrônico na visão do cliente. Revista de Administração do Unisal, v.3, n.3, mai. 2013. Disponível em: $\quad$ <http://www.revista.unisal.br/sj/index.php/RevAdministracao/article/view/235>. Acesso em: 08 out. 2020.

Como o marketplace pode alavancar vendas dentro e fora do e-commerce. ECOMMERCE BRASIL WEBSITE. Disponível em: $<$ https://www.ecommercebrasil.com.br/artigos/como-o-marketplace-pode-alavancarvendas-dentro-e-fora-do-e-commerce/>. Acesso em: 09 out. 2020.

Comportamento do consumidor. NEILPATEL WEBSITE. Disponível em: $<$ https://neilpatel.com/br/blog/comportamento-do-consumidor/>. Acesso em: 27 out. 2020. 
Cresce a importância do marketplace no comércio eletrônico brasileiro, defende head do Ebit/Nielsen. E-COMMERCE BRASIL WEBSITE. Disponível em: $<$ <ttps://www.ecommercebrasil.com.br/noticias/marketplace-no-brasil-ebit/>. Acesso em: 08 out. 2020.

DE MORAIS, Davi pinheiro. 0 marketplace: análise da relação de consumo em prol do fornecedor e a responsabilidade civil das intermediadoras de produtos e serviços. Faculdade Baiana de Direito, 2019. Disponível em: <http://portal.faculdadebaianadedireito.com.br/portal/monografias/davi\%20pinheiro\%20 de\%20morais.pdf.>. Acesso em: 09 nov. 2020.

Desafios para consolidar o crescimento dos marketplaces. E-COMMERCE BRASIL WEBSITE. Disponível em: <https://www.ecommercebrasil.com.br/artigos/desafios-para-consolidar-o-crescimentodos-marketplaces/>. Acesso em: 09 out. 2020.

DIAS, Claúdia Augusto. GRUPO FOCAL: técnica de coleta de dados em pesquisas qualitativas. $2000 . \quad$ Disponível em: https://www.brapci.inf.br/_repositorio/2010/12/pdf_2fbfd6231b_0013748.pdf. Acesso em: 17 de out. 2020

eBay, O primeiro Marketplace do Mundo!. ACADEMIA DO ECOMMERCE WEBSITE. Disponível em: <https://academiadoecommerce.com/artigo/ebay-o-primeiromarketplace-do-mundo>. Acesso em: 23 out. 2020.

E-Commerce No Brasil Em 2020: Entenda O Cenário Atual E Tendências. NEILPATEL WEBSITE. Disponível em: https://neilpatel.com/br/blog/e-commerce-nobrasil/. Acesso em: 11 nov. 2020.

Efeitos da mudança no perfil do consumidor. A CRÍTICA WEBSITE. Disponível em: <https://www.acritica.com/opinions/efeitos-da-mudanca-no-perfil-do-consumidor>. Acesso em: 01 out. 2020.

Entenda o comportamento do consumidor e aumente as suas vendas. ECOMMERCE BRASIL WEBSITE. Disponível em: 
<https://www.ecommercebrasil.com.br/artigos/comportamento-do-consumidor-2/>. Acesso em: 27 out. 2020.

Estudo novos hábitos digitais em tempos de covid-19. SOCIEDADE BRASILEIRA DE VAREJO E CONSUMO (SBVC) WEBSITE. Disponível em: $<$ http://sbvc.com.br/novos-habitos-digitais-em-tempos-de-covid-19/>. Acesso em: 07 out. 2020.

FRANCO, Renata de Souza; MAIA, Leonardo Caixeta de Castro; FILHO, Rafael Gontijo de Souza. Avaliação do Nível de Serviço ao Cliente no Contexto do Marketplace da Empresa Alfa. Revista Ciências Administrativas, Fortaleza, v.26, n.1, p.01-12, jan. 2020. Disponível em: <https://periodicos.unifor.br/rca/article/view/e9382>. Acesso em: 16 set. 2020.

Hipersegmentação: mudança no perfil do consumidor abre novas oportunidades. E-COMMERCE BRASIL WEBSITE. Disponível em: $<$ https://www.ecommercebrasil.com.br/noticias/hipersegmentacao-mudanca-no-perfildo-consumidor-abre-novas-oportunidades/>. Acesso em: 31 set. 2020.

Lista com os 5 melhores marketplaces do brasil - versão 2019. GYRAMAIS WEBSITE. Disponível em: <https://gyramais.com.br/blog/melhores-marketplacesbrasil/>. Acesso em: 28 out. 2020.

O Desenvolvimento do E-commerce no Brasil. ADMINISTRADORES WEBSITE. Disponível em: <https://administradores.com.br/artigos/o-desenvolvimento-do-ecommerce-no-brasil>. Acesso em: 08 out. 2020.

MARKETPLACE. PORTAL SEBRAE WEBSITE. Disponível em: <https://m.sebrae.com.br/Sebrae/Portal\%20Sebrae/UFs/CE/Anexos/Cartilha\%20Canais \%20de\%20Comercializa\%C3\%A7\%C3\%A30\%20-\%20Marketplace.pdf>. Acesso em: 17 set. 2020.

Marketplace: a evolução do e-commerce. NEXLAYER WEBSITE. Disponível em: <https://nexlayer.net/marketplace-evolucao-e-commerce/>. Acesso em: 21 out. 2020. 
Marketplace Online no Brasil: 0 que é, Exemplos, Vantagens e Desvantagens. OLIST BLOGSPOT. Disponível em: https://blog.olist.com/marketplace-online-conceitoexemplos-vantagens-e-desvantagens/. Acesso em: 28 out. 2020.

Marketplace: o que é, como funciona, vantagens e exemplos. NEILPATEL WEBSITE. Disponível em: <https://neilpatel.com/br/blog/marketplace/>. Acesso em: 15 out. 2020.

Marketplace: o que é, suas vantagens e desvantagens. E-COMMERCE BRASIL WEBSITE. Disponível em: <https://www.ecommercebrasil.com.br/artigos/marketplacevantagens-desvantagens/>. Acesso em: 21 out. 2020.

Mercado de marketplace no brasil: será que este segmento merece a sua atenção? IUGU WEBSITE. Disponível em: <https://iugu.com/blog/mercado-demarketplace-no-brasil/>. Acesso em: 22 out. 2020.

O crescimento das classes $C$ e $\mathbf{D}$ no mercado de vendas online. E-COMMERCE BRASIL WEBSITE. Disponível em: $<$ https://www.ecommercebrasil.com.br/artigos/crescimento-classes-c-d-mercadovendas-online/>. Acesso em: 27 out. 2020.

OLIVEIRA, Josiane Silva de. Representações das relações entre cultura, consumo e etnia: as representações culturais das mulheres negras no mercado consumidor brasileiro. Revista de Administração da UNIMEP, v. 9, n. 2, mai. ago. 2011, p. 108130. Disponível em: https://www.redalyc.org/articulo.oa?id=273719433006. Acesso em: 27 out. 2020.

o marketing da Amazon. BH1 WEBSITE. Disponível em: <http://www.bh1.com.br/marcas-mais-famosas/amazon/>. Acesso em: 23 out. 2020.

O novo perfil do consumidor brasileiro e a transformação digital no varejo. NIELSEN WEBSITE. Disponível em: $<$ https://www.nielsen.com/br/pt/insights/article/2019/o-novo-perfil-do-consumidorbrasileiro-e-a-transformacao-digital-no-varejo/>. Acesso em: 27 out. 2020. 
O panorama do mercado de marketplace no brasil. E-COMMERCE BRASIL WEBSITE. Disponível em: <https://www.ecommercebrasil.com.br/artigos/o-panoramado-mercado-de-marketplace-no-brasil/>. Acesso em: 08 out. 2020.

O que é comportamento do consumidor? Qual sua importância?. MINDMINERS WEBSITE. Disponível em: <https://mindminers.com/blog/o-que-comportamentoconsumidor/>. Acesso em: 27 out. 2020.

O que é e-commerce?, CLIMBA COMMERCE WEBSITE. Disponível em: $<$ https://www.climba.com.br/blog/o-que-e-e-commerce-loja-virtual/>. Acesso em: 16 set. 2020.

O que é marketplace e como funciona este canal de venda? NUVEMSHOP BLOGSPOT. Disponível em: <https://www.nuvemshop.com.br/blog/o-que-emarketplace/>. Acesso em: 22 out. 2020.

O que é marketplace? Veja as vantagens e desvantagens. E-COMMERCE BRASIL WEBSITE. Disponível em: <https://www.ecommercebrasil.com.br/artigos/marketplacevantagens-e-desvantagens/>. Acesso em: 17 set. 2020.

Pandemia do coronavírus acelera mudança no perfil do consumidor brasileiro. SENAI WEBSITE. Disponível em: https://senaimt.ind.br/noticias/1767/pandemia-docoronavirus-acelera-mudanca-no-perfil-do-consumidor-brasileiro. Acesso em: 01 out. 2020.

Pandemia do coronavírus faz e-commerce explodir no brasil. ISTOÉ DINHEIRO WEBSITE. Disponível em: <https://www.istoedinheiro.com.br/pandemia-do-coronavirusfaz-e-commerce-explodir-no-brasil/>. Acesso em: 03 out. 2020.

Para sobrevivência e-commerces aderem aos marketplaces. E-COMMERCE BRASIL WEBSITE. Disponível em: $<$ https://www.ecommercebrasil.com.br/artigos/sobrevivencia-marketplaces/>. Acesso em: 09 out. 2020.

Perfil do consumidor moderno: o que mudou nos últimos anos. FAZENDA CONTABILIDADE BLOGSPOT. 
$<$ https://blog.fazendacontabilidade.com.br/perfil-do-consumidor-moderno-o-que-mudounos-ultimos-anos/>. Acesso em: 31 set. 2020.

Pesquisa revela perfil de consumidores no varejo online. FOLHA DE PERNAMBUCO WEBSITE. Disponível em: $<$ https://www.folhape.com.br/economia/pesquisa-revela-perfil-dos-consumidores-dovarejo-online/131507/>. Acesso em: 27 out. 2020.

PIOVESAN, Armando; TEMPORINI, Edméa Rita. Pesquisa exploratória: procedimento metodológico para o estudo de fatores humanos no campo da saúde pública. Rev. Saúde Pública n.29 (4): 318-25, 1995. Disponível em: https://www.scielo.br/pdf/rsp/v29n4/10.pdf. Acesso em: 17 nov. 2020.

Por que é tão importante ficar por dentro do comportamento do consumidor? PRINTI WEBSITE. Disponível em: <https://www.printi.com.br/blog/por-que-e-taoimportante-ficar-por-dentro-do-comportamento-do-consumidor>. Acesso em: 27 out. 2020.

SALVADOR, Mauricio. Gerente de E-commerce. 1르 edição. São Paulo: Ecommerce School, 2013.

SCHIFFMAN, Harvey Richard. Sensação e percepção. 5. Ed. Rio de Janeiro: LTC, 2005.

SCHIFFMAN, L. G.; KANUK, L.L. Comportamento do Consumidor. 9.ed. Rio de Janeiro:

LTC, 2009.

SILVA, Pâmella Ferreira da Silva; VILELA, Ricardo do Nascimento; VIEIRA, Sérgio Ricardo Franco; CRUZ, Lucineide A.M. O Desenvolvimento do E-commerce no Brasil. Disponível em: https://administradores.com.br/artigos/o-desenvolvimento-do-ecommerce-no-brasil. Acesso em: 08 de outubro 2020

SOLOMON, Michael R. O Comportamento do Consumidor - Comprando, possuindo e sendo. 11.ed. Porto Alegre: Bookman, 2016. 
Tudo o que você precisa saber sobre o Mercado Livre. IDEIAS MERCADO LIVRE WEBSITE. Disponível em: <https://ideias.mercadolivre.com.br/sobre-mercadolivre/tudo-o-que-voce-precisa-saber-sobre-o-mercado-livre/>. Acesso em: 17 nov. 2020. 


\section{APÊNDICE 1 - Roteiro de entrevistas}

"Olá, bom dia, boa tarde ou boa noite!

Eu me chamo Milena Cohen e estou no último período do curso de Administração da PUC-RJ. Para finalizar o meu trabalho de Conclusão de Curso, preciso que me ajude respondendo algumas perguntas a seguir. Será de extrema importância para mim e garanto que não levará muito tempo.

Desde já obrigada.

Bom, será dividido em 2 partes: para começarmos irei passar um vídeo e fazer umas perguntas, em seguida, acessaremos o site do Mercado Livre e farei as últimas perguntas, tudo bem?

Podemos começar?"

\section{Perfil do Entrevistado}

Nome do entrevistado (a):

Idade:

Profissão:

Gênero:

Tem acesso fácil à internet?

1. Você sabe o que significa o termo marketplaces?

2. Você já realizou alguma compra online em marketplaces? Caso positivo, costuma realizar constantemente? 
"No ano de 2019, o Mercado Livre foi o marketplace com melhor desempenho no Brasil e alcançou $R \$ 3,1$ bilhões em vendas, de acordo o artigo divulgado pela Gyra+., em julho de 2020. Com isso, navegando por sua página, abordaremos algumas perguntas relacionadas em específico a este marketplace."

\section{Perguntas sobre Percepção do Consumidor sobre o Mercado Livre}

3. O que mais chamou a sua atenção ao entrar no site do Mercado Livre?

4. O que você associa quando lembra do Mercado Livre?

5. Quais produtos você associa serem vendidos no Mercado Livre?

6. Ao navegar na Internet, você já se deparou, ao menos uma vez, com propagandas do Mercado Livre e foi direcionado ao site deles? Se sim, é algo recorrente para você?

\section{Perguntas sobre a Atitude do Consumidor com o Mercado Livre}

7. O que você prefere, comprar online, em marketplaces ou presencialmente, em lojas físicas? Por quê?

8. Você já realizou compras no site do Mercado Livre? Você gosta do site?

9. Ao usar a plataforma do Mercado Livre, você considera a navegação por esta fácil e intuitiva? Você consegue achar os produtos que está procurando facilmente no site?

10. O que você acha do design da plataforma do Mercado Livre? O que você acha de suas cores?

11. Você considera a compra via este site fácil e intuitiva?

12. Para você, há pontos de melhoria na plataforma do Mercado Livre? Caso sim, quais? 


\section{Perguntas sobre Percepção do Consumidor}

13. O que mais chamou a sua atenção ao entrar no site do Mercado?

14. O que você associa quando lembra do Mercado Livre?

15. Quais produtos você associa serem vendidos no Mercado Livre?

16. Ao navegar na Internet, você já se deparou, ao menos uma vez, com propagandas do Mercado Livre e foi direcionado ao site deles? Se sim, é algo recorrente para você? 


\section{APÊNDICE 2 - COMPILADO DE ENTREVISTAS}

1. Você sabe o que significa o termo marketplaces?

2. Você já realizou alguma compra online em marketplaces? Caso positivo, costuma realizar constantemente?

"No ano de 2019, o Mercado Livre foi o marketplace com melhor desempenho no Brasil e alcançou $R \$ 3,1$ bilhões em vendas, de acordo o artigo divulgado pela Gyra+., em Julho de 2020. Com isso, navegando por sua página, abordaremos algumas perguntas relacionadas em especifico a este marketplace."

\section{Perguntas sobre Percepção do Consumidor sobre o Mercado Livre}

3. O que mais chamou a sua atenção ao entrar no site do Mercado Livre?

4. O que você associa quando lembra do Mercado Livre?

5. Quais produtos você associa serem vendidos no Mercado Livre?

6. Ao navegar na Internet, você já se deparou, ao menos uma vez, com propagandas do Mercado Livre e foi direcionado ao site deles? Se sim, é algo recorrente para você?

\section{Perguntas sobre a Atitude do Consumidor com o Mercado Livre}

7. $\bigcirc$ que você prefere, comprar online, em marketplaces ou presencialmente, em lojas físicas? Por quê?

8. Você já realizou compras no site do Mercado Livre? Você gosta do site?

9. Ao usar a plataforma do Mercado Livre, você considera a navegação por esta fácil e intuitiva? Você consegue achar os produtos que está procurando facilmente no site?

10. O que você acha do design da plataforma do Mercado Livre? O que você acha de suas cores? 
11. Para você, há pontos de melhoria na plataforma do Mercado Livre? Caso sim, quais?

\section{ENTREVISTA 1}

Nome do entrevistado (a): Camille Schwartz

Idade: $\mathbf{2 1}$

Profissão: Estudante de odontologia

Gênero: Feminino

Tem acesso fácil à internet? Sim

1. Você sabe o que significa o termo marketplaces?

R: Não, não sei.

2. Você já realizou alguma compra online em marketplaces? Caso positivo, costuma realizar constantemente?

R: Já. Costumo.

"No ano de 2019, o Mercado Livre foi o marketplace com melhor desempenho no Brasil e alcançou $\mathrm{R} \$ 3,1$ bilhões em vendas, de acordo o artigo divulgado pela Gyra+., em Julho de 2020. Com isso, navegando por sua página, abordaremos algumas perguntas relacionadas em especifico a este marketplace."

\section{Perguntas sobre Percepção do Consumidor sobre o Mercado Livre}

3. O que mais chamou a sua atenção ao entrar no site do Mercado Livre? 
R: Eu acho que são aquelas propagandas que ficam na parte superior do site.

4. O que você associa quando lembra do Mercado Livre?

R: Você diz em relação aos produtos? (Pode ser qualquer característica.) Suplementos, eletrônicos e o preço. E por ter uma variedade de lojas dentro dele, você consegue encontrar uma variedade de preços.

5. Quais produtos você associa serem vendidos no Mercado Livre?

R: Suplementos, equipamentos de academia. Principalmente na época da quarentena entrei bastante para procurar aparelhos desse tipo, acho que não só eu como muitas outras pessoas.

6. Ao navegar na Internet, você já se deparou, ao menos uma vez, com propagandas do Mercado Livre e foi direcionado ao site deles? Se sim, é algo recorrente para você?

R: Sim, muito recorrente.

Perguntas sobre a Atitude do Consumidor com o Mercado Livre

7. O que você prefere, comprar online, em marketplaces ou presencialmente, em lojas físicas? Por quê?

R: Com certeza prefiro comprar online, só em relação a eletrônicos que eu fico um pouco em dúvida. Mas a vantagem de chegar em casa é essencial para mim.

8. Você já realizou compras no site do Mercado Livre? Você gosta do site?

R: Sim, já realizei e gosto, mas não é minha plataforma preferida.

9. Ao usar a plataforma do Mercado Livre, você considera a navegação por esta fácil e intuitiva? Você consegue achar os produtos que está procurando facilmente no site?

R: Sim, acho de fácil manuseio, bem intuitivo. 
10. O que você acha do design da plataforma do Mercado Livre? O que você acha de suas cores?

R: Eu confesso que a "cor amarela" é uma cor que chama atenção, mas eu não acho legal para um site, mas o designe acho bem atualizado.

11. Para você, há pontos de melhoria na plataforma do Mercado Livre? Caso sim, quais?

R: Eu acho que uma coisa que me incomoda bastante, é quando você vai comprar uma coisa usada, de uma pessoa física, você não tem contato direto com o vendedor, muitos não colocam telefone, e às vezes postam foto de internet e não do produto original e não dá para saber como está, de fato, o produto. Isso me incomoda bastante.

\section{ENTREVISTA 2}

Nome do entrevistado (a): Alberto Cohen

Idade: 51

Profissão: Empresário

Gênero: Masculino

Tem acesso fácil à internet? Sim

1. Você sabe o que significa o termo marketplaces?

R: Sim, sei o que significa. Significa "vendas e compras online, onde a gente compra pelas grandes marcas mundiais".

2. Você já realizou alguma compra online em marketplaces? Caso positivo, costuma realizar constantemente?

R: Sim, já realizei. Costumo realizar constantemente. Porque a gente consegue comprar nas melhores marcas, nos melhores preços, porque a 
concorrência é maior então a gente consegue fazer uma boa pesquisa e, no final, realizar uma boa compra. Além disso, eu tenho uma empresa na qual eu trabalho com vários marketplaces, os grandes marketplaces e eu vendo por lá meus produtos, que são relógios e é um sucesso, com a pandemia teve um crescimento, multiplicou por 5 o faturamento e a tendência é crescer cada vez mais, é o futuro,

"No ano de 2019, o Mercado Livre foi o marketplace com melhor desempenho no Brasil e alcançou $R \$ 3,1$ bilhões em vendas, de acordo o artigo divulgado pela Gyra+., em Julho de 2020. Com isso, navegando por sua página, abordaremos algumas perguntas relacionadas em específico a este marketplace."

Perguntas sobre Percepção do Consumidor sobre o Mercado Livre

3. O que mais chamou a sua atenção ao entrar no site do Mercado Livre?

R: O site do Mercado Livre ele é realmente diferenciado, ele é muito fácil de mexer, de você chegar aos produtos e ele tem uma variedade de produtos muito grande, esse é o diferencial dele. Você pode comprar desde a pasta de dente à sua televisão de casa, qualquer outra coisa. Então ele tem de tudo, você pode comprar qualquer coisa, esse é o grande diferencial dele.

4. O que você associa quando lembra do Mercado Livre?

R: Associo a compras. Qualquer item, hoje, quando eu penso em comprar, pode ser uma pasta de dente ou um eletrônico, uma geladeira, seja o que for, o primeiro lugar que eu vou é no Mercado Livre, que eu sei que lá tem todos os produtos.

5. Quais produtos você associa serem vendidos no Mercado Livre?

R: Os produtos que eu costumo comprar, normalmente, e que tem preço bom eu compro lá, um exemplo eu gosto de comprar vinho lá, o mesmo vinho que eu compro nas lojas físicas eu compro lá pela metade do preço. Recentemente eu precisei comprar copos para minha casa, achei exatamente o copo que queria lá e, pô, pela metade do preço das grandes lojas físicas. Então, você faz uma pesquisa de preço, consegue um preço melhor e ele têm o "'mercado full", né? Que te entrega em 24 horas, então você compra o produto e no dia seguinte está na sua casa. 
6. Ao navegar na Internet, você já se deparou, ao menos uma vez, com propagandas do Mercado Livre e foi direcionado ao site deles? Se sim, é algo recorrente para você?

R: Sim, sempre. Recebo sempre no meu email, nas minhas redes sociais notícias do Mercado Livre.

\section{Perguntas sobre a Atitude do Consumidor com o Mercado Livre}

7. O que você prefere, comprar online, em marketplaces ou presencialmente, em lojas físicas? Por quê?

R: Incomparável. Hoje em dia, a gente já está acostumado a comprar pelos marketplaces, só vou na loja quando eu preciso ver o produto na mão ou experimentar. Mas, normalmente, o que eu não preciso experimentar ou ver o produto, porque eu já conheço, eu já compro pelo marketplace e, principalmente, pelo Mercado Livre, que eu considero o melhor para comprar.

Mas, assim, você falou que prefere comprar pelo marketplace os itens que você não experimenta. Mas, você considera isso uma parcela relevante dos seus produtos?

R: São muito poucos itens que você não consegue comprar pela internet e, hoje em dia, tem essa vantagem de, no Mercado Livre, se em uma semana você não gostar do produto, você pode devolver. Então você compra, experimenta, se por acaso ficou pequeno, ficou grande, não era o que você esperava, você "mete" no Correios de volta, que chega lá, eles estornam na mesma hora, porque o mercado pago deles é muito bom.

8. Você já realizou compras no site do Mercado Livre? Você gosta do site?

R: Sim, gosto muito do site, muito bom.

9. Ao usar a plataforma do Mercado Livre, você considera a navegação por esta fácil e intuitiva? Você consegue achar os produtos que está procurando facilmente no site? 
R: Super fácil. Ele te responde tudo, você clica ali, ele já vai te dando o andamento. Sem dificuldade nenhuma, tive que cancelar, outro dia, uma compra foi super simples de fazer o cancelamento, tudo muito simples.

10. O que você acha do design da plataforma do Mercado Livre? O que você acha de suas cores?

R: Espetacular, adoro. Amo o amarelinho, chama a atenção, gosto de ver aquele amarelinho. Sou fã do Mercado Livre.

11. Para você, há pontos de melhoria na plataforma do Mercado Livre? Caso sim, quais?

R: Não, só acho que eles deveriam enviar cupom de desconto para mim melhor.

\section{ENTREVISTA 3}

Nome do entrevistado (a): Raphaela Serruya

Idade: 22

Profissão: Estudante

Gênero: Feminino

Tem acesso fácil à internet? Sim

1. Você sabe o que significa o termo marketplaces?

R: Acho que sim.

2. Você já realizou alguma compra online em marketplaces? Caso positivo, costuma realizar constantemente?

R: Sim e costumo realizar constantemente.

"No ano de 2019, o Mercado Livre foi o marketplace com melhor desempenho no Brasil e alcançou $R \$ 3,1$ bilhões em vendas, de acordo o artigo divulgado pela Gyra+., em 
Julho de 2020. Com isso, navegando por sua página, abordaremos algumas perguntas relacionadas em especifico a este marketplace."

\section{Perguntas sobre Percepção do Consumidor sobre o Mercado Livre}

3. O que mais chamou a sua atenção ao entrar no site do Mercado Livre?

R: Acho que a cor amarela.

4. O que você associa quando lembra do Mercado Livre?

R: Compras.

5. Quais produtos você associa serem vendidos no Mercado Livre?

R: Nossa, tudo. Desde coisas para a casa, quando estava fazendo obras, minha luva de muay thai, coisas para natação e até chocolate, minha irmã já comprou.

6. Ao navegar na Internet, você já se deparou, ao menos uma vez, com propagandas do Mercado Livre e foi direcionado ao site deles? Se sim, é algo recorrente para você?

R: Sim, mas esporádico. Acho que outros aparecem mais.

\section{Perguntas sobre a Atitude do Consumidor com o Mercado Livre}

7. O que você prefere, comprar online, em marketplaces ou presencialmente, em lojas físicas? Por quê?

R: Roupas em loja física, mas, no geral, em marketplace.

8. Você já realizou compras no site do Mercado Livre? Você gosta do site? R: Sim, gosto.

9. Ao usar a plataforma do Mercado Livre, você considera a navegação por esta fácil e intuitiva? Você consegue achar os produtos que está procurando facilmente no site?

R: Fácil e intuitiva.

10. O que você acha do design da plataforma do Mercado Livre? O que você acha de suas cores?

R: Acho que é bem marcante, chama atenção. Amarelo = mercado livre. 
11. Para você, há pontos de melhoria na plataforma do Mercado Livre? Caso sim, quais?

R: Não, porque eu gosto muito.

\section{ENTREVISTA 4}

Nome do entrevistado (a): Beatriz Cherman

Idade: 71

Profissão: Historiadora

Gênero: Feminino

Tem acesso fácil à internet? Sim

1. Você sabe o que significa o termo marketplaces?

R: Marketing é uma propaganda, mas marketplace eu não sei.

2. Você já realizou alguma compra online em marketplaces? Caso . positivo, costuma realizar constantemente?

R: Sim, mas realizei compras médias durante a pandemia e no mercado livre.

"No ano de 2019, o Mercado Livre foi o marketplace com melhor desempenho no Brasil e alcançou $R \$ 3,1$ bilhões em vendas, de acordo 0 artigo divulgado pela Gyra+., em Julho de 2020. Com isso, navegando por sua página, abordaremos algumas perguntas relacionadas em especifico a este marketplace."

Perguntas sobre Percepção do Consumidor sobre o Mercado Livre

3. O que mais chamou a sua atenção ao entrar no site do Mercado Livre? 
R:Primeiro, o fato de aparecer o meu nome "Olá, Beatriz, o que você procura?".

4. O que você associa quando lembra do Mercado Livre?

R: Venda online.

5. Quais produtos você associa serem vendidos no Mercado Livre?

R: Todos, presentes para netos, utensílios domésticos.

6. Ao navegar na Internet, você já se deparou, ao menos uma vez, com propagandas do Mercado Livre e foi direcionado ao site deles? Se sim, é algo recorrente para você?

R: Sim, mas eu bloqueei os cookies do site. Então não aparece constantemente.

\section{Perguntas sobre a Atitude do Consumidor com o Mercado Livre}

7. O que você prefere, comprar online, em marketplaces ou presencialmente, em lojas físicas? Por quê?

R: Prefiro muito mais presencialmente, porque eu tenho uma idade mais avançada, então vou no preferencial.

8. Você já realizou compras no site do Mercado Livre? Você gosta do site?

R: Sim, mas apenas por causa da pandemia.

9. Ao usar a plataforma do Mercado Livre, você considera a navegação por esta fácil e intuitiva? Você consegue achar os produtos que está procurando facilmente no site?

R:Sim, muito fácil.

10. O que você acha do design da plataforma do Mercado Livre? O que você acha de suas cores? 
R: O design não é nada moderno, é bem antiquado, a gente já está tão acostumado que nem olha mais. Mas pelo menos a gente já associa aquele design ao mercado livre.

11. Para você, há pontos de melhoria na plataforma do Mercado Livre? Caso sim, quais?

R: Não, por enquanto, eu gostei muito. Fui muito bem atendida. E o mercado livre mostra sempre a origem do produto e eu consigo conversar com o fornecedor.

\section{ENTREVISTA 5}

Nome do entrevistado (a): Betty Cohen

Idade: 45

Profissão: Administradora

Gênero: Feminino

Tem acesso fácil à internet? Sim

1. Você sabe o que significa o termo marketplaces?

R:Sei, são várias marcas dentro de um site.

2. Você já realizou alguma compra online em marketplaces? Caso positivo, costuma realizar constantemente?

R: Sim, costumo realizar constantemente.

"No ano de 2019, o Mercado Livre foi o marketplace com melhor desempenho no Brasil e alcançou $R \$ 3,1$ bilhões em vendas, de acordo o artigo divulgado pela Gyra+., em 
julho de 2020. Com isso, navegando por sua página, abordaremos algumas perguntas relacionadas em especifico a este marketplace."

\section{Perguntas sobre Percepção do Consumidor sobre o Mercado Livre}

3. O que mais chamou a sua atenção ao entrar no site do Mercado Livre?

R: A quantidade de produtos.

4. O que você associa quando lembra do Mercado Livre?

R: Preço.

Mas preço você diz pela variedade de preços que têm na plataforma ou por ser a opção mais barata?

R: Não, por eu poder encontrar uma grande variedade de fornecedores, escolhendo, assim, o que tem o melhor preço.

5. Quais produtos você associa serem vendidos no Mercado Livre?

R: Normalmente, produtos de casa e produtos farmacêuticos.

6. Ao navegar na Internet, você já se deparou, ao menos uma vez, com propagandas do Mercado Livre e foi direcionado ao site deles? Se sim, é algo recorrente pra você?

R: Sim, algumas vezes. É algo recorrente.

Perguntas sobre a Atitude do Consumidor com o Mercado Livre

7. O que você prefere, comprar online, em marketplaces ou presencialmente, em lojas físicas? Por quê?

R: Tirando roupas e calçados, eu prefiro comprar pela internet. Roupas e calçados eu ainda compro bastante em lojas físicas.

Pela questão de experimentar ou tem algum outro ponto?

R: Isso, pela questão de experimentar e porque eu ainda acho que a troca pode ser um pouco trabalhosa. Então, eu prefiro ir na loja experimentar. 
E os outros produtos, você prefere comprar via marketplace, por que motivo? Você disse o preço, né? Por poder encontrar o melhor preço, né?

R: E pela comodidade de eu não ter que sair da minha casa e chegar na minha casa.

Mesmo tendo a demora do frete entregar na sua casa?

R: Sim, mesmo com a demora.

8. Você já realizou compras no site do Mercado Livre? Você gosta do site? R: Sim, já. Gosto bastante.

9. Ao usar a plataforma do Mercado Livre, você considera a navegação por esta fácil e intuitiva? Você consegue achar os produtos que está procurando facilmente no site?

R: Sim, acho que basta colocar o nome e a marca do produto, já vêm várias empresas que vendem esse produto.

10. O que você acha do design da plataforma do Mercado Livre? O que você acha de suas cores?

R: Eu acho cafona.

Cafona você diz por ser atemporal ou por ser muito antigo, pouco moderno?

R: É, pouco moderno, mas funcional, que você acha tudo e é fácil de visualizar,

E você acha marcante ou irrelevante?

R: Acho bem marcante.

11. Para você, há pontos de melhoria na plataforma do Mercado Livre? Caso sim, quais?

R: Não, acho que tudo funciona bem.

\section{ENTREVISTA 6}


Nome do entrevistado (a): Giulia Cohen

Idade: 21

Profissão: Estudante de designe

Gênero: Feminino

Tem acesso fácil à internet? Sim

1. Você sabe o que significa o termo marketplaces?

R: Eu sei por alto, mas se quiser pode me explicar um pouco.

2. Você já realizou alguma compra online em marketplaces? Caso positivo, costuma realizar constantemente?

R: Sim, eu compro bastante livro na Amazon.

"No ano de 2019, o Mercado Livre foi o marketplace com melhor desempenho no Brasil e alcançou $\mathrm{R} \$ 3,1$ bilhões em vendas, de acordo 0 artigo divulgado pela Gyra+., em Julho de 2020. Com isso, navegando por sua página, abordaremos algumas perguntas relacionadas em especifico a este marketplace."

Perguntas sobre Percepção do Consumidor sobre o Mercado Livre

3. O que mais chamou a sua atenção ao entrar no site do Mercado Livre?

R: É a facilidade de acesso. Eu fiz uma pesquisa anteontem sobre velas e, agora, quando entrei de novo, elas voltaram para primeira página de busca. Então, consigo ver o que já pesquisei antes.

4. O que você associa quando lembra do Mercado Livre?

R: Agilidade e diversidade.

5. Quais produtos você associa serem vendidos no Mercado Livre? 


\section{R: Produtos internacionais.}

6. Ao navegar na Internet, você já se deparou, ao menos uma vez, com propagandas do Mercado Livre e foi direcionado ao site deles? Se sim, é algo recorrente para você?

R: Não, não é recorrente, mas já apareceu.

\section{Perguntas sobre a Atitude do Consumidor com o Mercado Livre}

7. O que você prefere, comprar online, em marketplaces ou presencialmente, em lojas físicas? Por quê?

R: Eu prefiro, agora, durante a pandemia, no marketplace, mas antes presencial.

8. Você já realizou compras no site do Mercado Livre? Você gosta do site?

R: Já realizei e acho o site muito bom, eficiente.

9. Ao usar a plataforma do Mercado Livre, você considera a navegação por esta fácil e intuitiva? Você consegue achar os produtos que está procurando facilmente no site?

R: Sim, consigo e acho fácil.

10. O que você acha do design da plataforma do Mercado Livre? O que você acha de suas cores?

R: Eu acho que a primeira página é bastante ergonômica, consegue ter bastante visibilidade do que está acontecendo. As cores você consegue diferenciar também.

11. Para você, há pontos de melhoria na plataforma do Mercado Livre? Caso sim, quais?

R: Não. 


\section{ENTREVISTA 7}

Nome do entrevistado (a): Gabriel Cohen

Idade: 19

Profissão: Estudante

Gênero: Masculino

Tem acesso fácil à internet? Sim

1. Você sabe o que significa o termo marketplaces?

R: Sei. Inclusive trabalho numa empresa que utiliza várias plataformas de marketplace e mercado livre é umas das nossas top vendas e a gente gosta muito de trabalhar junto.

Vocês vendem na plataforma? Vocês são varejistas?

R: Sim, a gente vende nossos produtos nas plataformas de marketplace.

Quais produtos vocês vendem?

R: Relógio, principalmente.

Você já realizou alguma compra online em marketplaces?

R: Sim, além de vender, já realizei diversas compras pessoais.

"No ano de 2019, o Mercado Livre foi o marketplace com melhor desempenho no Brasil e alcançou $R \$ 3,1$ bilhões em vendas, de acordo o artigo divulgado pela Gyra+., em Julho de 2020. Com isso, navegando por sua página, abordaremos algumas perguntas relacionadas em especifico a este marketplace."

Perguntas sobre Percepção do Consumidor sobre o Mercado Livre

3. O que mais chamou a sua atenção ao entrar no site do Mercado Livre? 
R: 0 que eu gosto bastante do site do Mercado Livre é a facilidade que você pode encontrar os seus produtos com bastante clareza e diferenciar o seu alvo para compras.

4. O que você associa quando lembra do Mercado Livre?

R: Eu associo uma ótima relação entre o comprador e o vendedor do produto, que consegue ter uma conversa com bastante clareza.

5. Quais produtos você associa serem vendidos no Mercado Livre?

R: Relógios e eletrônicos.

E só uma pergunta relacionada à resposta anterior. Você disse que a "conversa é bem clara", mas isso você diz pelo lado de consumidor ou varejista que está vendendo na plataforma?

R: Para ambos os lados, eu já tive problema quando eu fui comprar alguns produtos, como consumidor, e consegui ter um contato bom com o varejista.

6. Ao navegar na Internet, você já se deparou, ao menos uma vez, com propagandas do Mercado Livre e foi direcionado ao site deles? Se sim, é algo recorrente para você?

R: Sim, diversas vezes no Facebook aparecem propagandas para mim.

Perguntas sobre a Atitude do Consumidor com o Mercado Livre

7. O que você prefere, comprar online, em marketplaces ou presencialmente, em lojas físicas? Por quê?

R: Prefiro comprar online. Hoje em dia, acho que a ascendência de comprar seus produtos online vem crescendo cada vez mais.

E isso para qualquer modalidade de produtos, né?

R: Para a maioria, têm alguns produtos que eu me incomodo por conta de vestuário e experimentar o tamanho, mas a maioria acho que tem como comprar online.

Mas e essa questão de peça, você consegue comprar online ou não? 
R: Eu já comprei online, mas a maioria das vezes eu compro física, mas têm vezes que estava melhor comprar online que eu experimentei fisicamente, mas comprei online.

Por questões de preço, né?

R: Sim.

E os outros produtos que você costuma comprar, você compra online por quê? Pela comodidade, pelo preço?

R:Pela facilidade e pelo número de promoções online que eu percebo.

8. Você já realizou compras no site do Mercado Livre? Você gosta do site?

R: Sim, gosto do site.

Sua experiência foi boa?

R: Sim, foi boa, meu produto chegou no prazo, os paramentos vieram normais, foi tudo perfeito.

9. Ao usar a plataforma do Mercado Livre, você considera a navegação por esta fácil e intuitiva? Você consegue achar os produtos que está procurando facilmente no site?

R: Sim, além de achar uma plataforma de fácil acesso, como eu disse antes, tem bastante clareza o site e consegue entender bem as áreas do site.

Você sempre conseguiu achar o produto que está procurando ou teve dificuldade nisso?

R: Sempre que eu tentei achar o produto, eu consegui. Nunca tive dificuldades.

10. O que você acha do design da plataforma do Mercado Livre? O que você acha de suas cores?

R: Bom, acho que é uma plataforma boa, com uma cor forte que é amarela e que já tem seu vínculo, pois quando lembramos de Mercado livre, esse amarelo do Mercado Livre já vem na cabeça. 
11. Para você, há pontos de melhoria na plataforma do Mercado Livre? Caso sim, quais?

R: Não, não tenho nenhuma melhoria não.

\section{ENTREVISTA 8}

Nome do entrevistado (a): Priscila Libman

Idade: $\mathbf{2 1}$

Profissão: Estudante

Gênero: Feminino

Tem acesso fácil à internet? Sim

1. Você sabe o que significa o termo marketplaces?

R: Sei.

2. Você já realizou alguma compra online em marketplaces? Caso positivo, costuma realizar constantemente?

R:Já, não realizo constantemente.

"No ano de 2019, o Mercado Livre foi o marketplace com melhor desempenho no Brasil e alcançou $\mathrm{R} \$ 3,1$ bilhões em vendas, de acordo 0 artigo divulgado pela Gyra+., em Julho de 2020. Com isso, navegando por sua página, abordaremos algumas perguntas relacionadas em especifico a este marketplace."

Perguntas sobre Percepção do Consumidor sobre o Mercado Livre

3. O que mais chamou a sua atenção ao entrar no site do Mercado Livre? R: 0 amarelo. 
4. O que você associa quando lembra do Mercado Livre?

\section{R: Compras.}

5. Quais produtos você associa serem vendidos no Mercado Livre?

R: Coisas de casa.

6. Ao navegar na Internet, você já se deparou, ao menos uma vez, com propagandas do Mercado Livre e foi direcionado ao site deles? Se sim, é algo recorrente para você?

R: Já, é recorrente.

\section{Perguntas sobre a Atitude do Consumidor com o Mercado Livre}

7. O que você prefere, comprar online, em marketplaces ou presencialmente, em lojas físicas? Por quê?

\section{R: Presencialmente.}

8. Você já realizou compras no site do Mercado Livre? Você gosta do site?

R: Já, gosto do site.

9. Ao usar a plataforma do Mercado Livre, você considera a navegação por esta fácil e intuitiva? Você consegue achar os produtos que está procurando facilmente no site?

R: Sim.

10. O que você acha do design da plataforma do Mercado Livre? O que você acha de suas cores?

\section{R: Eu acho um pouco feio.}

11. Para você, há pontos de melhoria na plataforma do Mercado Livre? Caso sim, quais?

\section{R: Deixar mais bonito esteticamente.}




\section{ENTREVISTA 9}

Nome do entrevistado (a): Henry Cherman

Idade: 74

Profissão: Químico

Gênero: Masculino

Tem acesso fácil à internet? Sim

1. Você sabe o que significa o termo marketplaces?

R: Não.

2. Você já realizou alguma compra online em marketplaces? Caso positivo, costuma realizar constantemente?

R: Sim, mas não constantemente.

"No ano de 2019, o Mercado Livre foi o marketplace com melhor desempenho no Brasil e alcançou $\mathrm{R} \$ 3,1$ bilhões em vendas, de acordo 0 artigo divulgado pela Gyra+., em Julho de 2020. Com isso, navegando por sua página, abordaremos algumas perguntas relacionadas em especifico a este marketplace."

\section{Perguntas sobre Percepção do Consumidor sobre o Mercado Livre}

3. O que mais chamou a sua atenção ao entrar no site do Mercado Livre?

\section{R: As cores e os produtos que aparecem na primeira página.}

4. O que você associa quando lembra do Mercado Livre?

R: Sinceramente, nada.

5. Quais produtos você associa serem vendidos no Mercado Livre?

R: Acredito que a maioria das "bugigangas".

6. Ao navegar na Internet, você já se deparou, ao menos uma vez, com propagandas do Mercado Livre e foi direcionado ao site deles? Se sim, é algo recorrente para você? 
R: Não apareceu.

\section{Perguntas sobre a Atitude do Consumidor com o Mercado Livre}

7. O que você prefere, comprar online, em marketplaces ou presencialmente, em lojas físicas? Por quê?

R: No momento de pandemia, online é melhor.

8. Você já realizou compras no site do Mercado Livre? Você gosta do site? R: Talvez, há muito tempo.

9. Ao usar a plataforma do Mercado Livre, você considera a navegação por esta fácil e intuitiva? Você consegue achar os produtos que está procurando facilmente no site?

R: Não perguntado.

10. O que você acha do design da plataforma do Mercado Livre? O que você acha de suas cores?

R: Eu gostei do design.

11. Para você, há pontos de melhoria na plataforma do Mercado Livre? Caso sim, quais?

R: Eu acho que as coisas têm que ficar claras, mas está bom.

\section{ENTREVISTA 10}

Nome do entrevistado (a): Caroline Nigri

Idade: 21

Profissão: Estudante

Gênero: Feminino

Tem acesso fácil à internet? Sim 
1. Você sabe o que significa o termo marketplaces?

R: Não.

2. Você já realizou alguma compra online em marketplaces? Caso positivo, costuma realizar constantemente?

R: Sim, mas não constantemente.

"No ano de 2019, o Mercado Livre foi o marketplace com melhor desempenho no Brasil e alcançou $R \$ 3,1$ bilhões em vendas, de acordo 0 artigo divulgado pela Gyra+., em Julho de 2020. Com isso, navegando por sua página, abordaremos algumas perguntas relacionadas em especifico a este marketplace."

\section{Perguntas sobre Percepção do Consumidor sobre o Mercado Livre}

3. O que mais chamou a sua atenção ao entrar no site do Mercado Livre?

R: A variedade, porque literalmente tudo que você quiser tem aqui.

4. O que você associa quando lembra do Mercado Livre?

R: Eu associo a produtos básicos e tudo, na verdade, tem no mercado livre.

5. Quais produtos você associa serem vendidos no Mercado Livre?

R: Tudo, até coisas aleatórias.

6. Ao navegar na Internet, você já se deparou, ao menos uma vez, com propagandas do Mercado Livre e foi direcionado ao site deles? Se sim, é algo recorrente para você?

R: Acho que sim, mas não é recorrente.

Perguntas sobre a Atitude do Consumidor com o Mercado Livre

7. O que você prefere, comprar online, em marketplaces ou presencialmente, em lojas físicas? Por quê?

R: Presencialmente em loja física. 
8. Você já realizou compras no site do Mercado Livre? Você gosta do site? R: Sim, gosto do site.

9. Ao usar a plataforma do Mercado Livre, você considera a navegação por esta fácil e intuitiva? Você consegue achar os produtos que está procurando facilmente no site?

\section{R: Acho ridículo de fácil.}

10. O que você acha do design da plataforma do Mercado Livre? O que você acha de suas cores?

R: Eu acho que já ficou muito marcante, eu gosto, porque eu associo muito.

11. Para você, há pontos de melhoria na plataforma do Mercado Livre? Caso sim, quais?

R: Focar mais no contato com o vendedor, mas isso não é algo urgente. Acho a plataforma boa.

\section{ENTREVISTA 11}

Nome do entrevistado (a): Stella Cotta

Idade: 22

Profissão: Estudante

Gênero: Feminino

Tem acesso fácil à internet? Sim

1. Você sabe o que significa o termo marketplaces?

R: Não.

2. Você já realizou alguma compra online em marketplaces? Caso positivo, costuma realizar constantemente?

R: Sim, mais ou menos. Costuma, mas não sempre. 
"No ano de 2019, o Mercado Livre foi o marketplace com melhor desempenho no Brasil e alcançou $R$ \$ 3,1 bilhões em vendas, de acordo o artigo divulgado pela Gyra+., em Julho de 2020. Com isso, navegando por sua página, abordaremos algumas perguntas relacionadas em especifico a este marketplace."

\section{Perguntas sobre Percepção do Consumidor sobre o Mercado Livre}

3. O que mais chamou a sua atenção ao entrar no site do Mercado Livre?

R: A grande disponibilidade produtos, tanto usados como novos.

4. O que você associa quando lembra do Mercado Livre?

R: Eu penso muito em coisa usada.

5. Quais produtos você associa serem vendidos no Mercado Livre?

R: Quando não acho na Amazon ou Americanas, eu uso o mercado livre, acho que é preconceito por ter muita coisa usada.

6. Ao navegar na Internet, você já se deparou, ao menos uma vez, com propagandas do Mercado Livre e foi direcionado ao site deles? Se sim, é algo recorrente para você?

R: Sim, muito recorrente.

\section{Perguntas sobre a Atitude do Consumidor com o Mercado Livre}

7. O que você prefere, comprar online, em marketplaces ou presencialmente, em lojas físicas? Por quê?

R: Prefiro presencial, mas nessa pandemia, o jeito é online.

8. Você já realizou compras no site do Mercado Livre? Você gosta do site? R: Sim, gosto.

9. Ao usar a plataforma do Mercado Livre, você considera a navegação por esta fácil e intuitiva? Você consegue achar os produtos que está procurando facilmente no site?

R: Considero, acho com facilidade. 
10. O que você acha do design da plataforma do Mercado Livre? O que você acha de suas cores?

R: Eu acho ok, acho boa.

11.Para você, há pontos de melhoria na plataforma do Mercado Livre? Caso sim, quais?

R: Eu acho o frete caro, na Amazon Prime por exemplo tem o frete grátis e entrega rápida, que é o que me faz querer comprar.

\section{ENTREVISTA 12}

Nome do entrevistado (a): Fernanda Dawidiwitsch

Idade: 21

Profissão: Estudante

Gênero: Feminino

Tem acesso fácil à internet? Sim

1. Você sabe o que significa o termo marketplaces?

R: Não.

2. Você já realizou alguma compra online em marketplaces? Caso positivo, costuma realizar constantemente?

R: Sim, na Amazon, Magazineluiza e, principalmente, Mercado Livre. E realizo constantemente.

"No ano de 2019, o Mercado Livre foi o marketplace com melhor desempenho no Brasil e alcançou $R \$ 3,1$ bilhões em vendas, de acordo 0 artigo divulgado pela Gyra+., em Julho de 2020. Com isso, navegando por sua página, abordaremos algumas perguntas relacionadas em especifico a este marketplace." 


\section{Perguntas sobre Percepção do Consumidor sobre o Mercado Livre}

3. O que mais chamou a sua atenção ao entrar no site do Mercado Livre?

R: As propagandas que ficam passando na tela inicial, passa mais ou menos propagandas que tem descontos. E as ofertas relacionadas aos produtos que procurei na minha última visita.

4. O que você associa quando lembra do Mercado Livre?

R: Tenho a ideia de ser a entrega mais rápida, então sempre que preciso de algo mais rápido entro no mercado livre.

5. Quais produtos você associa serem vendidos no Mercado Livre?

R: Já comprei muitos livros, cabo de iphone. Coisas mais simples, mas que sei que chegam rápido.

6. Ao navegar na Internet, você já se deparou, ao menos uma vez, com propagandas do Mercado Livre e foi direcionado ao site deles? Se sim, é algo recorrente para você?

R: Sim, várias vezes.

Perguntas sobre a Atitude do Consumidor com o Mercado Livre

7. O que você prefere, comprar online, em marketplaces ou presencialmente, em lojas físicas? Por quê?

R: Pela confiança do produto: lojas físicas. Mas pela praticidade: lojas online.

8. Você já realizou compras no site do Mercado Livre? Você gosta do site?

R: Sim, eu sempre fui bem atendida. Rastreiam o produto

9. Ao usar a plataforma do Mercado Livre, você considera a navegação por esta fácil e intuitiva? Você consegue achar os produtos que está procurando facilmente no site?

R: Acho bastante intuitiva. Geralmente entro focada no que quero, então não sou levada para comprar outros produtos. Mas acho muito bom todo o processo de compra.

10. O que você acha do design da plataforma do Mercado Livre? O que você acha de suas cores? 
R: Eu acho o amarelo chamativo.

11. Para você, há pontos de melhoria na plataforma do Mercado Livre? Caso sim, quais?

R: Não, acho que a plataforma está ótima. 